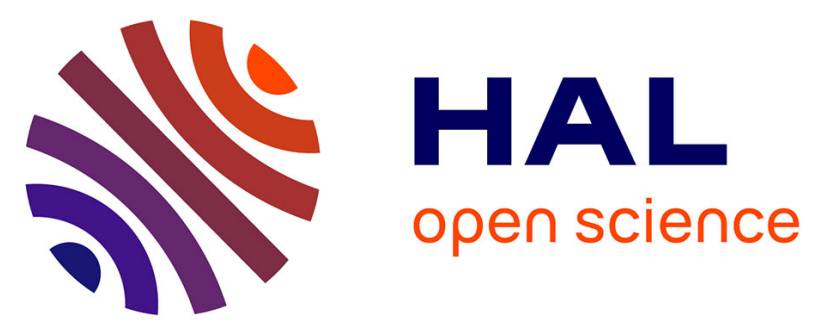

\title{
Deciphering of six blocks of Gondwanan origin within Eastern Indonesia (South East Asia)
}

\author{
Michel Villeneuve, Rossana Martin, Hervé Bellon, Jean-Pierre Réhault, \\ Jean-Jacques Cornée, Olivier Bellier, Safri Burhannuddin, Florent \\ Hinschberger, Christian Honthaas, Christophe Monnier
}

\section{To cite this version:}

Michel Villeneuve, Rossana Martin, Hervé Bellon, Jean-Pierre Réhault, Jean-Jacques Cornée, et al.. Deciphering of six blocks of Gondwanan origin within Eastern Indonesia (South East Asia). Gondwana Research, 2010, 18 (2-3), pp.420-437. 10.1016/j.gr.2009.12.011 . insu-00462636

\section{HAL Id: insu-00462636 \\ https://hal-insu.archives-ouvertes.fr/insu-00462636}

Submitted on 25 Oct 2011

HAL is a multi-disciplinary open access archive for the deposit and dissemination of scientific research documents, whether they are published or not. The documents may come from teaching and research institutions in France or abroad, or from public or private research centers.
L'archive ouverte pluridisciplinaire HAL, est destinée au dépôt et à la diffusion de documents scientifiques de niveau recherche, publiés ou non, émanant des établissements d'enseignement et de recherche français ou étrangers, des laboratoires publics ou privés. 
Deciphering of six blocks of Gondwanan origin within Eastern Indonesia (South East Asia)

\title{
Michel Villeneuve ${ }^{\underline{a}}$, , Rossana Martin${ }^{\text {b}}$, , Hervé Bellon ${ }^{\mathrm{c}}$, Jean-Pierre Réhault ${ }^{\mathrm{c}}$, Jean- Jacques Cornée ${ }^{\mathrm{d},}$, Olivier Bellier ${ }^{\mathrm{e}}$, Safri Burhannuddin ${ }^{\mathrm{f}}$, Florent Hinschberger ${ }^{\mathrm{g}}$, Christian Honthaas ${ }^{\mathrm{h}}$, Christophe Monnier ${ }^{\mathrm{i}}$
}

a EA 4229, Université de Provence, Case 67, 3 place Victor Hugo, 13331 Marseille Cedex 03, France

b Département de Géologie Paléontologie, Université de Genève, 13 rue des Maraichers, 1205 Genève, Switzerland

c Université européenne de Bretagne, UMR CNRS 6538, UBO, IUEM, Place Nicolas

Copernic, 29280 Plouzané, France

d UMR CNRS 5125, Université Claude Bernard, 2 rue Raphael Dubois, 69622 Villeurbanne Cedex, France

e CEREGE, UMR CNRS 6635, Université Paul Cézanne, BP 80, 13345 Aix-en Provence, France

f Department of Geology, University of Hasanuddin, Jalan Perintis Kemerdekaan Km. 10, Makassar 17411, Indonesia

g UPRES EA 2100, Lab. GéEAC, Université François Rabelais, Parc de Grandmont, 37200 Tours, France

${ }^{\text {h }}$ Université P et M Curie, 4, place Jussieu, case 110, 75252 Paris Cedex 05, France

i UMR CNRS 6112, Laboratoire de Planétoplogie et Géodynamique, Université de Nantes, 2 , rue de la Houssinière, BP 92208, 44322 Nantes Cedex 03, France

\begin{abstract}
The French Indonesian research programs, both conducted on land and offshore in the Banda Sea basins area, have led us to formulate a new interpretation of the East Indonesian geological components. In this area we distinguish, within the three main tectonic plates (Eurasian, Indo-Australian and Philippine-Pacific), seven blocks. Six blocks are deciphered as issued from the north-eastern Gondwanan margin and only one (the Halmahera block) issued from the Pacific plate. Among the Gondwanan blocks, two of them, namely Timor (probably originates from "Greater India") and Kolonodale (or the Argo block) came from the north-west Australian margin. The Lucipara, Seram and Banggai-Sula blocks originated from the western extension of the Papua-New Guinea Island while the Irian Jaya block is still linked to the North Australian margin. The last one, the Halmahera block, originated from the Pacific plate, moved westward along the North Papua-New-Guinea margin up to its present position in the northern part of the Banda Sea area. Our interpretation is mainly based on the lithostratigraphic succession, the geological evolution and the Early Mesozoic paleoposition of these blocks with respect to the climatic environment deduced from micropaleontological studies.
\end{abstract}

According to previous studies, the Timor and Kolonodale blocks were detached from Gondwana during the Jurassic whereas the Lucipara, Seram and Banggai-Sula blocks were detached from Papua-New Guinea Island during the Neogene period. All these Gondwanan 
blocks collided with the Eurasian active margin, in the vicinity of Sulawesi Island: Timor and Kolonodale had joined the Eurasian margin by the end of the Paleogene, while Lucipara, Seram and Banggai-Sula collided with Sulawesi Island between the Middle Miocene to Middle Pliocene. After the collisions the last three blocks together with the Kolonodale block did not move again but suffered the opening of North and South Banda back-arc basins, by the Late Miocene. On the contrary, part of the Timor block moved south together with the southern margin of the south Banda basin and, later on during the middle Pliocene, collided with the northern Australian margin. The detachment of these blocks from the Gondwana margin, and their amalgamation with the Eurasian margin, are discussed and illustrated through palaeogeographic maps.

Keywords: East Indonesia; Indonesian blocks; North-eastern Gondwana margin fragmentation; Australia; Banda Sea basins; Tectonics; Plaeogeography

\section{Introduction}

The Gondwana supercontinent results from a "great continental gathering event" which took place between the "Rodinia supercontinent" ca $1000 \mathrm{Ma}$ ago, and the "Pangea supercontinent" ca 300 to $250 \mathrm{Ma}$ ago. The Gondwana supercontinent, located in the southern hemisphere and centred on the "South pole", extended from South America to the Australian block, from west to east respectively (e.g. [Meert and Lieberman, 2008] and [Santosh et al., 2009] ).

The southern margin of the Gondwana supercontinent was active until the end of the Palaeozoic (Carboniferous/Permian) while its northern margin underwent an extensive tectonic regime leading to the detachment of many large and smaller blocks. From the Cambrian to Devonian, blocks were detached from the north-western Gondwana margin and incorporated into the "Pangea supercontinent" during the "Variscan orogen". Meanwhile, during the Permian to Triassic periods, detached blocks from its north-eastern margin flowed to the North, crossing the Tethys Ocean, before colliding with the Asian active margin (e.g. [Metcalfe, 1993], [Metcalfe, 2006], [Murphy et al., 2009] and [Melleton et al., 2010] ).

This paper focuses on the blocks detached from the Gondwanan, Indian and/or Australian margins, and then accreted to the west Indonesian active margin, since the Late Eocene-Early Oligocene. The investigated area covers the eastern part of the Indonesia Archipelago, from Sulawesi in the West, to Irian Jaya in the East, over $2000 \mathrm{~km}$, and between the Molucca Sea to the north and Timor (or the Australian shelf) to the south, over $1500 \mathrm{~km}$ (Fig. 1a). It includes the Banda Seas which are surrounded by many islands and separated by several submerged rims, like Tukang Besi and Banda ridges. Such a geological domain requires studies both on land and off shore. Our investigations were undertaken between 1991 and 1999 within the framework of a large "French Indonesian cooperative program in oceanography", both on land and aboard Indonesian research vessels (mainly the Baruna Jaya III).

The major geological interest of the investigated area comes from its location at the junction of three major plates: the Eurasian (Sundaland), the Indian-Australian and the Pacific plates (Barber and Crow, 2003). These three major plates have converged towards the Eastern Indonesian area since the Triassic. Besides the three plates, our investigations allow us to 
distinguish seven contrasted blocks (or microcontinents). Six of them come from the northeastern margin of Gondwana and one from the Philippine-Pacific plate. However, some Gondwana-derived blocks (i.e. Timor, Lucipara and Irian Jaya) include a series belonging to the Sundaland or to the Philippine Sea plate.

Independently from their period of detachment from the Gondwana margin, these blocks drifted towards the active Eurasian margin and collided with it after the Oligocene, mainly in the Sulawesi area.

Our main aims are to challenge the definition of the geological characteristics of each block, subsequently to deduce their origin and period of detachment and finally to infer the timing and pattern of collision with the Eurasian margin. Based on the geological, geochronological and geophysical data available at present, including our own results obtained in the framework of the numerous cruises and trips of the cooperative French Indonesian program: ca 400 paleontological determinations allow us to date the stratigraphical units or formations and some selected K/Ar datings performed in Brest University are listed in Table 1.

\section{Previous works}

Since the middle of the twentieth century, the geological pattern of eastern Indonesia has drawn the attention of numerous geologists (e.g. Van Bemmelen, 1949) and, between [Katili, 1975] and [Hinschberger et al., 2005] , more than thirty different reconstructions have been proposed. However, few of them married stratigraphic and tectonic from both on land and offshore data. The substantial references are mainly mentioned in Hinschberger et al. (2005).

Marine data have been collected in the course of numerous "cruises" that were conducted mainly by the Scripps Oceanographic Institution, Woods Hole Oceanic Institution, ORSTOM, or by the Dutch, French and Australian teams in cooperation with Indonesian institutes such as the BPPT or the MGI and LIPI. The main research cruises were: "Atlantis II", 1976 (Bowin et al., 1980); "Indopac 7, 8 and 10", 1976 and 1977 (Silver and Moore, 1978); "Mariana 9", 1979 (Silver et al., 1983); "Rama 12", 1981 (Silver et al., 1983); "Corindon III, VII and IX”, 1981, 1982 and 1983 (Lapouille et al., 1985); "Kana Keoki”, 1983 ( [Breen et al., 1989] , [Silver et al., 1985] and [Silver et al., 1986] ); Snellius II, 1984 and 1985 ( [144], [Vroon et al., 1993] , [Vroon et al., 1996] and [Van Marle, 1991] ); "Geobandut", 1992 (Réhault et al., 1994), Banda Sea I, 1992 (Villeneuve et al., 1994), Banda Sea II, 1993 ( [Cornée et al., 1997] and [Honthaas et al., 1997] ), Banda Sea III, 1995 ( [Cornée et al., 1998] , [Honthaas et al., 1998] and [Honthaas et al., 1999] ), Image IV, 1998 ( [Hinschberger et al., 2000] and [Hinschberger et al., 2005] ). The main result of these cruises is to convert the "Indian ocean origin" of the Banda Sea floors into oceanic crusts of Neogene age. That "opens the door" to new interpretations about the Indonesian blocks transfers from the Asiatic to the Australian margins and vice versa.

\section{Geological framework: plates, blocks and basins evolution}

The East Indonesian area is bordered by the Eurasian, the Australian and the PhilippinePacific plates and includes seven continental blocks, two residual seas (Celebes Sea and Moluccas Sea) and seven Neogene basins (Fig. 1b). 


\subsection{Tectonic plates}

The three main tectonic plates (1,2 and 3), limited by "subduction" or "transcurrent" fault zones, are shown in Fig. 1b. Their lithostratigraphic successions are shown in Fig. 2. Sundaland and Philippine-Pacific plates present an alternation of sedimentary and volcanic formations corresponding to the evolution of an active margin. The Indo-Australian plate presents only a sedimentary succession related to the evolution of a passive margin, excepted in the Papua-New Guinea Island. Here we compare blocks and plates bearing similar formations and presenting concordant geological evolutions through time; such blocks could be a "good candidates" for "detached pieces" from the main tectonic plates.

\subsubsection{The Eurasian plate (Fig. 1 and Fig. 2)}

Its eastern margin outcrops in the northern and western arms of Sulawesi, in Sumba (Wensinck, 1997) and in the "Timor Allochthonous" ( [Villeneuve et al., 2004] and [Villeneuve et al., 2005] ). The islands of the Banda volcanic arc (Flores, Alor, Wetar, Romang and Damar) may have formed within this domain.

Based on investigations in the western arm of Sulawesi, the stratigraphic column (Fig. 2 and Fig. 3) shows a metamorphic basement corresponding to ophiolitic formations of the Jurassic to Middle Cretaceous Meratus fold belt (ages between 200 and $150 \mathrm{Ma}$ ) in Monnier et al. (1994) and Pubellier et al. (1998) (Fig 2) overlain by Paleogene to Neogene volcanic arc and volcano-detritic deposits. The Bantimala complex in the southern part of the western arm in Sulawesi consists of both metamorphic schists and ultrabasic rocks ( [Miyazaki et al., 1996] , [Sopaheluwakan, 1979] and [Wakita et al., 1996] ). Muscovite separated from the schist was dated at $111 \mathrm{Ma}$ by Obradowich cited by Sukamto, 1982; another age is yielded by Parkinson in the Pompangeo schist complex in central Sulawesi at $114 \mathrm{Ma}$, K/Ar ages from two metamorphic minerals (Parkinson, 1991). North of Ujung Pandang (Toraja area), in the Lamasi formation, tholeitic basalts are dated 158.5 \pm 5 Ma by Priadi, 1993 (sample NL30-C). The volcanic formations were investigated by [Van Leeuven, 1981] , [114] and [Bergman et al., 1996] , while sedimentary formations were investigated mainly by [59] and [Wilson and Bosence, 1996] .

\subsubsection{The Eurasian plate (Fig. 1 and Fig. 2)}

Its eastern margin outcrops in the northern and western arms of Sulawesi, in Sumba (Wensinck, 1997) and in the "Timor Allochthonous" ( [Villeneuve et al., 2004] and [Villeneuve et al., 2005] ). The islands of the Banda volcanic arc (Flores, Alor, Wetar, Romang and Damar) may have formed within this domain.

Based on investigations in the western arm of Sulawesi, the stratigraphic column (Fig. 2 and Fig. 3) shows a metamorphic basement corresponding to ophiolitic formations of the Jurassic to Middle Cretaceous Meratus fold belt (ages between 200 and $150 \mathrm{Ma}$ ) in Monnier et al. (1994) and Pubellier et al. (1998) (Fig 2) overlain by Paleogene to Neogene volcanic arc and volcano-detritic deposits. The Bantimala complex in the southern part of the western arm in Sulawesi consists of both metamorphic schists and ultrabasic rocks ( [Miyazaki et al., 1996] , [Sopaheluwakan, 1979] and [Wakita et al., 1996] ). Muscovite separated from the schist was dated at $111 \mathrm{Ma}$ by Obradowich cited by Sukamto, 1982; another age is yielded by Parkinson in the Pompangeo schist complex in central Sulawesi at $114 \mathrm{Ma}$, K/Ar ages from two metamorphic minerals (Parkinson, 1991). North of Ujung Pandang (Toraja area), in the 
Lamasi formation, tholeitic basalts are dated $158.5 \pm 5$ Ma by Priadi, 1993 (sample NL30-C). The volcanic formations were investigated by [Van Leeuven, 1981] , [114] and [Bergman et al., 1996] , while sedimentary formations were investigated mainly by [59] and [Wilson and Bosence, 1996] .

The "Initial Timor block" only includes the "Para-Autochthonous unit". Its lithostratigraphic succession (Fig. 3) points out a proximal marine sedimentation during the Permian and a deep marine sedimentation during the Middle to Late Triassic interval. The following Triassic to Middle Eocene deep marine sediments made of calcilutites and radiolarites, suggest a "breakup" by the Early Triassic. The "Allochthonous unit" (Fig. 3) coming from the Sundaland active margin, was overthrusted on it. According to Sopaheluwakan the thrusting of the "Mutis complex" on "initial Timor" took place at ca: $37.2+0.9 \mathrm{Ma}$ (Late Eocene).

We know that Paleogene sediments interbedded with volcanic deposits in the arc series of Sulawesi contain some Eocene "Anthracothere" fossils of Asiatic origin. This mammalian fossil was also found in the "Timor Allochthon" (Durocq, 1996). This suggests a strong connection between Timor and the South East Asia margin at a post Eocene time. Then both Para-Autochthonous and Allochthonous (Fig. 3-1c) units were then sealed by younger sediments of the Autochthonous unit (Fig. 4-4). The latter began with the Late Oligocene to Early Miocene Cablac oolithic limestones followed by the Miocene to Early Pliocene Miomaffo volcano-sedimentary formation that is, in the central basin, unconformably covered by the Late Pliocene to Pleistocene deposits (Fig. 4).

Regarding the Timor block, Kisar, Leti and Moa islands present similar characteristics, and contain comparable Permian and Triassic formations although they were slightly metamorphosed (Agustiyanto and Suparman, 1989). Roti and the northern part of Tanimbar hold the same radiolaritic formations as in the Jurassic series of the "Initial Timor block" ( [Jasin and Hailé, 1996] and [Shashida et al., 1999] ).

\subsubsection{Evolution of the Timor block}

The Timor block underwent a very long and complex geodynamic history partially published by [Villeneuve et al., 2004] , [Harris, 2006] , [Ishikawa et al., 2007] and [Kaneko et al., 2007]

The model presented here assumes that an initial part of Timor, herein referred to as the "Initial Timor block", deriving from the south, reached the Sunda plate by the Late Eocene $(37.2+0.9 \mathrm{Ma})$ when an ophiolitic nappe, the Mutis complex made of basalts dated at $153.6 \pm$ 3.4 Ma (Table 1) was obducted over it (Sopaheluwakan, 1990). This assemblage then collided with the Eurasian active margin by the Early Oligocene time before the deposition of the Cablac limestones. Afterwards, the Timor block was detached from the Sunda plate and moved to the south until its southward collision with the Australian continent by the Middle Pliocene, as attested by the age of a diorite within the Manamas volcanic series (sample T111 dated at 10.5 $\pm 1.2 \mathrm{Ma}$, Table 1). Since this time, the Timor block moved to the north northeast together with the Australian continent and is presently backthrusting the "South Banda basin". Consequently, the Timor "Allochthonous unit" (Fig. 3-1c) is considered as a part of the Eurasian active margin that was accreted to the "Initial Timor block" during its Oligocene collision with the Asian plate. 
The Kolbano unit (Fig. 1b), outcropping in the fore-zone south of Timor Island is considered part of the Australian shelf, amalgamated to the Timor mainland during the Middle Pliocene collision with the Australian continent.

\subsubsection{Origin of the Timor block}

The Timor block has long been considered as a part of the Australian margin and, for a majority of geologists, moved with this plate ( [Carter et al., 1976] , [Audley-Charles, 1988] , [Rangin et al., 1990] and [Charlton, 2001] ). However, [Parkinson, 1998] and [Charlton, 2000] hypothetically put the "Timor Allochthonous" along the Eurasian margin.

So, the problem is to identify the origin of the "Initial Timor block" corresponding to the "Para-Autochthonous" lithostratigraphic succession (Fig. 5). Martini et al. (2000) indicated a more southern Late Triassic palaeogeographic position than for the other blocks, according to fossil data. Yet, the Kolonodale block (see above) is inferred to have originated from the northwestern Australia Argo abyssal plain. So, the "initial Timor block" must have been located further south, during the Upper Triassic time.

Thus, two scenarii might be considered: 1) the Timor block came from the northern part of "Greater India" in the west, or 2) it approached from the south-eastern end of the Irian Jaya block. Considering the global plate kinematic evolution (Ricou, 1994), we favour the first hypothesis. It is to be noted that these Gondwanan blocks perfectly fit between India and Australia while the boundary of "Greater India" is still debated. Nevertheless, following the Li and Powell "fit" (2001) and the interpretation of Ali and Aitchison (2005), which borders "Greater India" by the "Wallaby-Zenith fracture zone", it is possible to remove the Timor block in the southernmost position relative to the other Indonesian blocks. However, under this palaeogeographical position, the "initial Timor block" detached from Gondwana during the Triassic should have collided with the "Sumatra/Java block" by the Cretaceous period. However, there is insufficient evidence for the Timor break-up in the Triassic period because a deep marine environment is not conclusive to date the Timor detachment. The hypothesis of a "Timor initial block" coming from southeast Papua seems unrealistic to us at present. In any case, Timor moved away from this present position along the north Australian margin. Thus, the origin of the initial Timor remains questionable.

\subsection{The Kolonodale block (noted 5 on Fig. 1 b and 5 on Fig. 4)}

\subsubsection{Characterisation}

This block is restricted to the central and eastern parts of Sulawesi Island and to the adjacent islands of Buton, Muna, Wowoni and Kabaena. It is separated from the western arm of Sulawesi by the "Poso Thrust fault" and from the eastern blocks by the "Tolo trench" and the "Batui thrust".

The first synthetic view of this area was delivered by Sukamto (1975). The central part was investigated by [106], [Parkinson, 1996] , [Parkinson, 1998] , [Gunawan, 1999] and [Villeneuve et al., 2002] . The north-eastern arm was studied by [Kundig, 1956] , [142] , [Rusmana et al., 1993a] , [129] , [156] and [Villeneuve et al., 2000] . The south-eastern arm was studied by [Helmers et al., 1989], [Rusmana et al., 1993a] , [129] , [143] and [156] , when the Buton Island was successively explored by [138] , [Fortuin et al., 1990] , [Davidson, 1991] and [Smith and Silver, 1991] . 
The Kolonodale block contains an ophiolitic nappe obducted onto a sedimentary pile that is resting on a metamorphic basement, widely prevalent on the south-eastern arm. The stratigraphic succession of the Sulawesi central part, well studied by [Gunawan, 1999] and [Villeneuve et al., 2001] , begins by an Upper Triassic carbonate platform ( [Cornée et al., 1994] and [Martini et al., 1997] ) followed by Liassic external shelf sediments and then by pelagic carbonates and radiolarites until the Upper Oligocene to Lower Miocene. The geological succession in the south-eastern arm of Sulawesi and in Buton Island can locally be slightly different from the central part of Sulawesi, especially with regard to the Triassic sedimentation.

The Kolonodale block was later affected by collisions with the Lucipara, Seram and BanggaiSula blocks. The middle Eocene ophiolitic nappe is dated at $44 \pm 4 \mathrm{Ma}$ (mean $\mathrm{K}$-Ar age of two different amphiboles, Table 1 and Monnier et al. (1994)). It represents the second largest ophiolitic nappe in the world and caps the sedimentary succession between ca 32 and $28 \mathrm{Ma}$ (see [106] , [Parkinson, 1996] , [Monnier et al., 1995] , [Gunawan, 1999] , [Villeneuve et al., 2002] and [Kadarusman et al., 2004] ).

\subsubsection{Evolution of the Kolonodale block}

In our interpretation, the Kolonodale block was obducted by the Sulawesi Eocene (Monnier et al, 1995) ophiolitic nappe during the Oligocene (Parkinson, 1991), and then collided with the western arm of Sulawesi during the Early Miocene. Parkinson (1991) preferred an eastern Mesozoic ophiolite with a westward intra-oceanic formation overthrusted by the end of the Oligocene. However, Kadarusman et al. (2004) admitted a westward obduction of these ophiolites onto an indefinite microcontinent while other authors favour a western Eurasian back-arc basin obducted eastward onto the Kolonodale block. Whatever the origin of the Sulawesi ophiolitic nappe, the most important element to validate our interpretation is to recognize the origin and amalgamation of the underlying Kolonodale block with the Eurasian margin.

\subsubsection{Origin of the Kolonodale block}

For some of the previous authors working in Timor, the East Sulawesi terranes, including the ophiolitic nappe, were probably detached from Irian Jaya ( [Audley-Charles et al., 1979], [Audley-Charles et al., 1988], [Ben Avraham, 1978] and [Daly et al., 1991] ). However, [Mubroto et al., 1994] , [Parkinson, 1998] , [Hall, 1996] and [Nichols and Hall, 1999] considered an Indian oceanic origin for this ophiolitic nappe, while for Kadarusman et al. (2004) the Sulawesi ophiolite came from the middle Pacific. The underlying "Kolonodale block" was neglected by many geologists and even undifferentiated from the Banggai-Sula block (Parkinson, 1991). [Martini et al., 2000] and [Martini et al., 2004] who worked on the Late Triassic formations of East Sulawesi, Timor and Seram evidenced an intermediate palaeogeographic position for the Kolonodale block with respect to the Late Triassic position of Timor and Seram. On the other hand, the pre break-up lithostratigraphy of the "Kolonodale block" is very similar to that of the Exmouth plateau (on the north-western Australian margin) ( [Hinz et al., 1978] , [Von Rad and Exon, 1983] , [Von Rad et al., 1989] and [Sager et al., 1992] ).

Consequently, we propose a north-western Australian origin for the Kolonodale block, suggesting that it is, in fact, the "Argo block" detached from the "Exmouth plateau" during the Callovian. This detachment gave way to the "Argo Abyssal plain". Ricou (1994) admitted 
a northward motion of the "Argo block" up to its junction with the Eurasian margin by the Early Eocene. According to Sager et al. (1992) the oldest magnetic anomaly recorded in the Argo abyssal plain, off the NW Australian margin, is M 26 (163 Ma). Our data perfectly match this scenario and consequently rebuff an Irian Jaya origin.

\subsection{The Lucipara block (noted 6 Fig. 1 b and 6 on Fig. 5)}

\subsubsection{Characterisation}

This block occupies a large part of the Banda Sea floor. We distinguish two main parts: the Tukang Besi platform (to the West) and the Banda ridges (to the East). It outcrops in a few small islands such as Kur, Penyu and Lucipara. Unfortunately, most of these islands are capped by Quaternary reefs or sediments. Only a few of them, such as Kur (Honthaas et al., 1997) and Fadol, exhibit some more ancient formations.

The main morphological and geological data were obtained during marine cruises ( [Silver et al., 1983] , [Cornée et al., 1998] , [Cornée et al., 2002] , [Honthaas et al., 1998] and [Honthaas et al., 1999] ). Only the upper part of the Lucipara block lithostratigraphic succession has been reconstructed to take into account land and marine data. The oldest neighbouring formation is the south-east Sulawesi ophiolite (see supra for its mean K/Ar age at $44 \pm 4 \mathrm{Ma}$, Monnier et al., 1994) was intruded by volcanism related to an Oligocene volcanic arc, dated on amphiboles from the basement rocks of Kur at ca $30 \mathrm{Ma}$ (Honthaas et al., 1997). The eastern margin of the Weber through consists of Carboniferous Triassic sediments. The global chronology based on twelve K/Ar ages carried on whole-rocks and separated minerals (Table 1) leads to point out the presence of an Early Oligocene magmatic arc (31.4 $\pm 1.8 \mathrm{Ma})$ and of a later large tectonometamorphic event that affected these rocks at ca 24 and $17 \mathrm{Ma}$, indirectly confirming the ages of the Banda ridges metamorphism (Silver et al., 1983). These metamorphic rocks were capped after the Lower Miocene by folded fluviatile sediments. Late Oligocene and Early Miocene reefal platforms were developed on the Banda ridges and were matched with Early Miocene volcanic material ( [Cornée et al., 1998] and [Cornée et al., 2002] ).

\subsubsection{Evolution of the Lucipara block}

By the Late Miocene (11 Ma), the Lucipara block began to collapse in the Tukang Besi platform (Fortuin et al., 1990) and the Banda ridges (Honthaas et al., 1997). At the same time, a local metamorphic event at ca 11-10 Ma was registered in the northern part of the Banda ridges (Silver et al., 1985); a volcanic arc linked to the northward motion of Australia was operating within the Lucipara block and the adjacent areas. The separation of Tukang Besi from the Banda ridges happened previously to the intra-arc South Banda Sea opening at ca 6.5 Ma ( [Honthaas et al., 1998] and [Hinschberger et al., 2001] ).

\subsubsection{Origin of the Lucipara block}

The Lucipara block was clearly identified as a specific block by Villeneuve et al. (1998). Previously, the Banda ridges including Seram and Buru were considered by Silver et al. (1985) as fragments that split from the Irian Jaya Bird's Head. For them, the Tamrau terrane was favoured as the Banda ridges primitive land. However Vroon et al. (1996), using Pb and $\mathrm{Nd}$ isotopes markers, preferred a rather Pacific origin for these Banda ridges. The Lucipara 
block lithostratigraphic succession (Fig. 5), until the Early Miocene, is very similar to that of the "Irian Jaya Mobile belt", including an Eocene ophiolite.

We consider the Lucipara block as a western extension of the "Mobile belt" terrane before its detachment from Irian Jaya during the Neogene. The separation time of the Lucipara block from the Irian Jaya is still debated; Smith and Silver (1991) supported a collision between Tukang Besi and the South East Arm of Sulawesi at about 13 Ma. However, obviously, the detachment from Irian Jaya happened earlier. The Irian Jaya Mobile belt and Lucipara block had a similar evolution until the end of the Oligocene, and their separation occurred at ca 24 Ma. Consequently, the Lucipara block displacement time, from Irian Jaya to Sulawesi, could be estimated between 24 and 13 Ma.

\subsection{The Seram block (noted 7 on Fig. 1 b and 7 on Fig. 6)}

\subsubsection{Characterisation}

This block includes Buru, Seram and small adjacent islands such as Ambon, as well as the submerged Sinta Ridge located between Buru, Tukang Besi ridge and the North Banda basin, the latter opening at around 12.5 Ma.

Even if Buru Island has been investigated by [Tjokosapoetro and Budhitrisna 1982] , [145] and [Fortuin et al., 1988] , only Seram has drawn the attention of most geologists and geophysicists: [Hailé, 1978] , [Audley-Charles, 1979] , [Letouzey et al., 1983] , [O'Sullivan et al., 1985] , [De Smet et al., 1989] , [Linthout et al., 1989] , [Linthout et al., 1991] , [Monnier et al., 2003] and [Martini et al., 2004] . Ambon was studied in the nineties by [Linthout and Helmers, 1994] and [Honthaas et al., 1999], as the Sinta Ridge that was dredged during the Banda Sea I cruise (Villeneuve et al., 1994).

In Ambon, Linthout et al. (1989) distinguished the western and the eastern parts separated by a NW-SE dextral strike-slip fault. In the western part, a metamorphic basement displaying Permian fossils supports a thick sedimentary pile beginning with the Tehuru flysch. In Buru and west Seram (Fig. 7), a Late Triassic carbonate platform outcrops together with Lower Jurassic flyschs and volcanic shales. They are covered by pelagic limestones, deposited from the Late Jurassic until the Eocene, followed by shales, sandstones and reef limestones of Oligocene to Lower Miocene age and before the Middle Miocene neritic limestones. Late Miocene deposits are lacking until the deposition of the Latest Miocene/Early Pliocene Salas blocks. This former tectonic melange was probably capped by an arc and then by a back-arc type ophiolitic nappe. Whole-rock $\mathrm{K}$-Ar ages are scattered between $19.7 \pm 2$ and $15 \pm 1.3 \mathrm{Ma}$ for this ophiolite that was subsequently obducted on west Seram at around 9-7 Ma ( [Linthout et al., 1991] and [Monnier et al., 2003] ). However, a younger arc operated within this backarc system between $15.3 \pm 1.2$ and $8.9 \pm 0.4 \mathrm{Ma}$, as evidenced by whole-rock K/Ar ages. Molasse sediments and reef limestones deposited from the Late Pliocene until recent times cover the oldest formations. An important unconformity between the Lower and the Upper Pleistocene yields evidence of a local tectonic event.

Buru Island only slightly differs from west Seram, because of the lack of Middle Jurassic deposits. In addition, Tjokosapoetro and Budhitrisna (1982) pointed out an unconformity between the Eocene and the Oligocene and also between the Oligocene and the Lower Miocene. Fortuin et al. (1988) highlighted a drowning in the Early/Middle Miocene and an uplift in the Late Miocene/Early Pliocene. 
Finally, dredged samples from the Sinta Ridge (Villeneuve et al., 1994) indicate an Upper Triassic carbonate platform, very similar to those of Sulawesi, Buru and Seram, capped by pelagic limestones of possible Cretaceous to Oligocene age.

\subsubsection{Evolution of the Seram block}

The lithostratigraphic succession characterising the Seram block is not truly indicative of the detachment of the Seram block from Irian Jaya, except for the lack of deposits recorded from the Late Miocene to the Early Pliocene, correlated with an uplift after Fortuin et al. (1988). Nevertheless, a Seram-Irian Jaya detachment by strike-slip faulting can be hypothesized along a proto-Sorong fault, corresponding to the "Lajur-Sorong fault" (Dow et al., 1986).

The geological map of these authors pointed out a sinistral strike-slip movement before the deposition of Middle to Late Miocene (14 to $10.5 \mathrm{Ma}$ ) volcano-sedimentary rocks on the conjugate Bird's Head terrane. The separation between Seram and Banggai-Sula blocks could have occurred between 20 and $14 \mathrm{Ma}$. Concerning the connection between the Seram and Sulawesi blocks, we have no clear indications of both modalities and ages. Hinschberger et al. (2000) constrained the North Banda basin opening, as a back-arc basin in a NW-SE direction, between 12.5 and $7.15 \mathrm{Ma}$ on the basis of whole-rock K/Ar ages of dredged lavas and of identification of magnetic anomalies). The subduction of the North Banda basin underneath the "Tolo trench" has been evidenced by several authors ( [Silver et al., 1983] , [Réhault et al., 1994] and [Hinschberger et al., 2000] ) with the development of an accretionary prism, but without any observable collision. However, the metamorphic event at ca 11-10 Ma ( [Silver et al., 1985] and [Villeneuve et al., 1998] ) evidenced for the Banda ridges could be linked to the collision between the Seram and Lucipara blocks. Monnier et al. (2003) indicated the presence of a northern block, most probably the Banggai-Sula block, separated from Seram by a short-lived back-arc-basin and volcanic arc.

We notice that the oblique collision between Seram and this northern block (Banggai-Sula block?) could have generated the ophiolite obduction on Seram and Ambon (Monnier et al., 2003). The modern (5 to $0.5 \mathrm{Ma}$ ) Ambon arc, operating in the southern part of the Seram block, is related to the subduction of the Irian Jaya plate (Honthaas et al., 1999). We, intentionally, do not evoke the paleomagnetic results demonstrating a $70^{\circ}$ anticlockwise rotation of Seram Island (Linthout et al., 1997) because the non-controlled rotation of small pieces of blocks in a general transpressive regime cannot be excluded.

\subsubsection{Origin of the Seram block}

Its origin is still open to debate. Silver et al. (1985) correlated the Banda ridges with the North Bird's Head terranes, but other geologists ( [Carter et al., 1976] , [Audley-Charles, 1988] , [Audley-Charles et al., 1988], [De Smet, 1989], [Daly et al., 1991], [Charlton, 2000] and [Charlton, 2001] ) favoured a paleoposition close to the Aru and Kai Islands, on the Australian margin. This scenario is supported by [Linthout et al., 1996] and [Linthout et al., 1997]. The metamorphic basement of Seram and Buru includes some Permian fossils whereas the Misool and Aru basements, capped by unfolded Early Palaeozoic sediments, are likely Precambrian. But, on the contrary, a similar Palaeozoic basement and related overlying sediments outcrop in the "Bird's Head Kemun terrane" with the exception of the Paleogene deposits. The former evoke a deep marine environment in Buru and Seram, as well as a shallow water carbonate platform in the "Kemum terrane". However, Eocene to Oligocene deep marine sediments have been reported in adjacent areas, like Onin peninsula and the 
Lengguru fold belt (Dow et al., 1986). Moreover, the Late Triassic shallow water carbonate platform also outcropping at Buru, Seram and Misool Islands enhanced this hypothesis. Consequently, we support the "Seram block" as a western extension of the "Bird's Head Kemun terrane".

\subsection{The Banggai-Sula block (noted 8 in Fig. $1 b$ and 8 in Fig. 6)}

\subsubsection{Characterisation}

This block includes the southern part of the Sulawesi north-eastern arm (Luwuk area), the archipelago of Banggai (NE of Sulawesi), the islands of Sula (or Taliabu), Mangole and Sulabesi in the northern part of the North Banda basin, and the Tomori basin located in front of the Banggai platform.

The Luwuk area was investigated by [Kundig, 1956] , [Rusmana et al., 1993a] , [129] , [142] and [Villeneuve et al., 2000] . Banggai and Sula Islands were investigated mainly by [Pigram et al., 1984] , [Pigram et al., 1985] , [154] , [Garrard et al., 1988] and [Ryacudu et al., 1993] , and the Tomori basin by petroleum companies: [Handiwiria, 1990] , [Davies, 1990] , [Abimanyu, 1990] and [Charlton, 1996] .

Its lithostratigraphic succession shows a Palaeozoic (Permian) metamorphic basement intruded by Triassic granites with $\mathrm{K}-\mathrm{Ar}$ and $\mathrm{Rb}-\mathrm{Sr}$ ages at ca 239-235 Ma (Pigram et al., 1984). The metamorphic basement of Mangole is cut by medium to coarse grained plutonic intrusions of different whole-rock K-Ar (Table 1) respectively at $287 \pm 6.7,220 \pm 5$ and 116 $\pm 2.7 \mathrm{Ma}$ and different compositions: gabbro, diorite and granite. We notice that both the ages and chemical compositions of the rocks are contrasted.

The first sedimentary deposits occurring in the Lower Jurassic are continental red beds and shallow marine clastics and carbonates. The Late Jurassic and the Lower Cretaceous are represented by shallow marine anoxic sediments intruded by volcanic rocks. The Upper Cretaceous to Lower Paleocene interval corresponds to pelagic limestones deposits.

On Sula Island there is a lack of deposits between the Upper Paleocene and the Lower Oligocene; from the Upper Oligocene to the Middle Miocene, a shallow water carbonate platform was built, including isolated reefs (i.e. Salodik Formation). By the Late Pliocene a new shallow water carbonate platform was developed (i.e. Pancoran Formation). Moreover, in the Banggai and Luwuk areas, the shallow carbonate platform begins by the Middle Paleocene and lasts until the Middle Pliocene with a possible gap during the Oligocene.

In the Tomori basin, the Lower Pliocene consists of a very thick formation that comprises sandstones and claystones. The main unconformity both in the Tomori basin (Davies, 1990) and in the Luwuk area (Villeneuve et al., 2000) occurred within the Middle Pliocene period.

\subsubsection{Evolution of the Banggai-Sula block}

As mentioned before, we postulate that during the ophiolitic obduction on Seram and Ambon, 9-7 Ma ago, the Banggai and Sula Islands were located in the vicinity of the Seram block. On the other hand, the Banggai-Sula indenter should have been close to Sulawesi when their North and North East arms began to move north-westward ( [Smith and Silver, 1991] and [Surmont et al., 1994] ) by the latest Miocene. According to Villeneuve et al. (2000) the final 
collision occurred at ca 3.5 Ma. Consequently, the duration of the movement from Seram to Sulawesi could be estimated between 5.5 and 3.5 Ma.

\subsubsection{Origin of the Banggai-Sula block}

There is a large consensus to correlate the Banggai-Sula block with the northern part of the Bird's Head. Only Pigram et al. (1985) have contested this point of view and proposed a more eastern origin, very close to the central Papua range. However, the lithostratigraphic successions of Banggai and Sula islands are very similar to those of the "Tamrau and Danau Jamar terranes", showing Triassic granitic intrusions and rhyolitic lavas, followed by Paleogene shallow water carbonate platform.

We agree with the general consensus that considers the Banggai-Sula block as a detached piece from the Bird's Head extension. From north to south, we should then encompass successively: the Lucipara block, the Banggai-Sula block and finally the Seram block even if the amalgamation process to the Eurasian margin, through the Banda Sea, has changed this order.

\subsection{The Irian Jaya block (noted 10 in Fig. 1 b and 10 on Fig. 6)}

The geological features of the Irian Jaya block point to the geological concordances between the Irian Jaya block (and mainly the Bird's Head) and the already exposed Lucipara, Seram and Banggai-Sula blocks.

\subsubsection{Characterisation}

The "Irian Jaya block" is one of the largest and most complex entities of the Indonesian area. It is restricted to New Guinea and its adjacent islands, such as Misool. It is a W-E elongated block with a very characteristic western end, the "Bird's Head", that is separated (1) from the Australian plate by the "Aiduna-Tarera fault zone" (Fig. 1b) and by the "Papuan thrust" in the southern part, (2) from the Banda area by the North Banda arc, and (3) from the Halmahera block by the Sorong fault.

Numerous geologists have worked there, mainly in eastern Papua-New Guinea. Those working in western Irian Jaya were mostly interested in the comparison between continental and oceanic plates ( [Dow and Sukamto, 1984], [Pubellier and Ego, 2002] and [Sapie and Cloos, 2004] ). Nevertheless, the geological map of the Indonesian part of Irian Jaya delivered by Dow et al. (1986) is a masterpiece of Irian Jayan geology.

Struckmeyer et al. (1993) distinguished more than 25 terranes in the whole "Papua" block and among them 14 in the western part. They recognized three types of terranes, mainly with: continental basement, oceanic rocks, or mixed rocks respectively. Hill and Hall (2002) also differentiated three main parts: 1) the "stable platform" to the south, which corresponds to the northern part of the unfolded Australian platform; 2) the "adjacent fold belt" with the same rocks but folded during the Miocene continent arc-collision; and 3) the northern "Mobile fold belt" with rocks of various origins (ophiolites and volcanic arc formations) folded and metamorphosed during the Pliocene orogen. Crowhurst et al. (1996) added the Melanesian fold belt to the northern island. Fig. 7 exhibits the main units and terranes of the western part of the Irian Jaya block with the probable position of Lucipara, Seram and Banggai-Sula blocks by the Early Miocene. 
The metamorphic basement of the Australian platform is either Precambrian or late Palaeozoic. The Tasman line is the virtual limit between the two types of metamorphic basements. Consequently, two types of terranes must be distinguished: the "Bird's Head terrane" with Australian affinities and the "Mobile belt terrane" with Pacific plate or mixed affinities.

In the crustal Bird's Head block, the lithostratigraphic succession starts with the basement, folded and metamorphosed by the end of Devonian (Fig. 6, Fig. 7, Fig. 8, Fig. 9 and Fig. 10a). This basement is unconformably overlain by Carboniferous to Triassic fluviatile or shallow marine sediments. The Jurassic and Cretaceous series are respectively deltaic sandstones and marine claystones. Paleocene sediments indicate a shallow marine environment with sandstones, claystones, anhydrites and minor limestones on the top. From the Eocene to the Late Miocene there is a pile of limestones with corals and algal reefs. Then, the Upper Miocene to Pliocene Klasafet Formation is composed of deep marine deposits while the Pliocene to Pleistocene sediments point to a shallow marine or flood plain environment. Two unconformities occurred: the first between the Late Miocene and the Pliocene and the second at the end of the Pliocene.

The areas adjacent to the Irian Jaya block (Fig. 7) display some differences. The northern "Tamrau terrane" and the "Lengguru fold belt" in the southeast show a basement with large Permian and/or Triassic granitic intrusions, while the Misool Island in the west exhibits a Late Triassic carbonate platform similar to those of Seram and Buru. A shallow water carbonate platform also occurs in Misool by the Upper Cretaceous ( [Pigram et al., 1982] and [Bailly et al., 2009] ).

The northern part of the "Mobile belt" presents a very different geological history with a succession of ophiolites, volcanic arc deposits and marine sediments (Fig. 6 and Fig. 10b). The lower part is a large ophiolitic nappe with a back-arc basin geochemical signature, Jurassic to Cretaceous in age according to the geological map by Dow et al. (1986) and the $\mathrm{K}-\mathrm{Ar}$ ages of $144 \pm 15$ and $157 \pm 16 \mathrm{Ma}$ of amphiboles separated from metagabbros HC 295 and HC 304 (Table 1). This ophiolite was thrusted on an oceanic sole attached to the Australian margin ca $66 \mathrm{Ma}$ (K/Ar age of amphiboles separated from a metagabbro HC 307, Table 1) but not directly on the margin. This result is in good accordance with the ages yielded by hornblendes from amphibolites dated at 68.3 and 65.5 Ma (Dow and Sukamto, 1984). The final obduction to the margin was Oligocene (Permana, 1995).

A microdioritic intrusive (sample 121) in the arc formations from the western Mobile belt is dated at $90 \pm 2.1 \mathrm{Ma}$ (Table 1$)$.

In the Central High Range, the Sepik volcanic arc operated during the Eocene. Calc-alkaline basalt has been dated at $43 \pm 1 \mathrm{Ma}$ (HC 194, Table 1, and in Monnier (1996)). This arc collided with the mainland at ca $40 \mathrm{Ma}$ ( [115] and [Pubellier et al., 2004] ).

Later on, a new back-arc basin took place during the Oligocene, generating the Cyclops basin. This basin was uplifted by the Early Miocene and a new magmatic arc originated in the Middle Miocene (Cyclops volcanic arc? Monnier et al., 1999). Late Miocene to Early Pliocene sediments were deposited in the Mamberamo basin up to the Pliocene collision as evidenced by Dow and Sukamto (1984). 


\subsubsection{Evolution of the Irian Jaya block}

According to Lee and Lawver (1995) the Irian Jaya "block" moved northward after the Gondwana break-up until its junction with the Philippine-Pacific plate, 15 Ma ago. $10 \mathrm{Ma}$ after, it moved to the West under the control of the Pacific plate. From 10 to $5 \mathrm{Ma}$, the foreland oceanic crust as long as $250 \mathrm{~km}$ subducted underneath the North Banda area. Since 5 Ma, the continental margin of the Bird's Head and Misool Island subducted beneath Seram giving way to the modern Ambon volcanic arc (Honthaas et al., 1999). Presently, the Irian Jaya island moved to the West by strike-slip movement along the "Aiduna-Tarera fault zone" (Pubellier and Ego, 2002).

\subsubsection{Origin of the Irian Jaya block}

An Australian plate origin for the Bird's head block is not contested. There are indeed large similarities between the Papua/Irian Jaya islands and the Australian microcontinent. The Proterozoic and Palaeozoic covers of the Australian block were drilled in the Arafura Sea while the Eastern Australian hercynian belt crops out in northern Papua and Irian Jaya.

4.6.4. Correlations between the Irian Jaya block and Lucipara, Seram and Banggai-Sula blocks

In Fig. 7, we correlate:

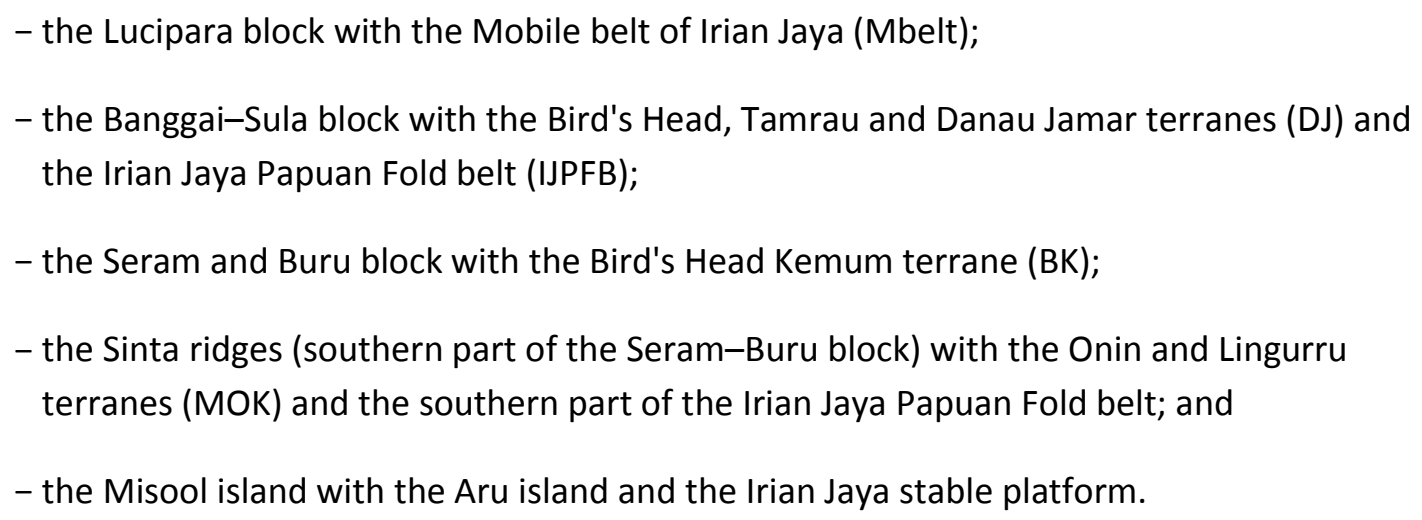

We note two points: 1) the northern Seram ophiolites do not outcrop in Irian Jaya and, 2) the Banggai-Sula and Seram-Buru blocks moved together away from the Irian Jaya block.

\subsection{The Halmahera block (noted 9 on Fig. 1b and 9a on Fig. 5)}

We have included this block in the paper in order to present an overall picture of the eastern Indonesian blocks.

\subsubsection{Characterisation}

This block includes the Halmahera and adjacent islands such as Bacan, Obi and Waigo. It is limited to the West by the Moluccas Sea and to the South by the Sorong fault. According to Hall and Nichols (1990) this plate results from the amalgamation of two different terranes at the end of the Pliocene: the western volcanic arc, comprising Halmahera, Bacan and Obi, and 
the eastern "Halmahera-Waigo ophiolitic terrane" which includes the eastern arm of Halmahera, Waigo and adjacent islands.

Numerous paleomagnetic studies performed by Jeffrey et al. (1996) and by Ali et al. (2001) on the rocks from Bacan and Obi demonstrated an equatorial position for the Middle Mesozoic ophiolites.

\subsubsection{Evolution of the Halmahera block}

The paleoposition of the Halmahera block may vary from author to author but an E-W movement is generally admitted. Halmahera block was in the vicinity of Papua ca $20 \mathrm{Ma}$ ago, near the Cenderawasih bay ca $10 \mathrm{Ma}$ ago, in the vicinity of the Bird's Head ca $5 \mathrm{Ma}$ ago, and is presently at the longitude of Buru Island (Nichols and Hall, 1999). The "Banggai-Sula block" moved westward, along the Sorong fault.

\subsubsection{Origin of the Halmahera block}

Halmahera block is considered by [Hall and Nichols, 1990] and [Nichols and Hall, 1999] as a part of the Philippine-Pacific plate moving westward or north-westward. According to Honza and Fujuoka (2004), Halmahera is the southern end of the Philippine archipelago. Pubellier et al. (2003a) have suggested an amalgamation of the Philippine Sea plate with the Australian plate by the Oligocene ( $32 \mathrm{Ma}$ ). An amalgamated block, formed by the Halmahera block and the Bird's Head terrane, detached from the rest of Irian Jaya since $15 \mathrm{Ma}$, was also proposed by Pubellier et al. (2003b). On the other hand, Vroon et al. (1996) supported an Irian Jayan origin for the continental fragments exposed on Bacan Island. Whatever the origin of the southern part, the main part of the Halmahera blocks likely belongs to the Philippine plate.

\section{Discussion}

Among the numerous islands and submerged crustal blocks, we evidenced six blocks of Gondwanan origin. The seventh one, the Halmahera block, is ascribed to the Pacific plate. But the main geological question is to constrain their amalgamation in the eastern Indonesian area.

This is beyond the scope of the present paper because the amalgamation of the Gondwanan blocks (i.e. Timor, Kolonodale, Lucipara, Seram, Banggai-Sula and Irian Jaya) with the Eurasian margin is highly speculative. If the motion of the Eurasian (Sundaland), IndianAustralian and Pacific plates is relatively well-constrained, this is not the case for the Gondwanan blocks.

But the recent acquisition of: 1) multiple and various geophysical data carried out both during offshore and onshore fieldwork; 2) paleontological and K/Ar dates; and 3) geochemical affinities of magmatism, allows us to drastically reduce the numerous geodynamic scenarii.

Using the [Scotese et al., 1979] and [135] palaeogeographic maps we tried to locate the socalled Indonesian blocks (i.e. Timor, Kolonodale, Lucipara, Seram, Banggai-Sula) before the break-up of Gondwana (Fig. 8a, ca $237 \mathrm{Ma}$ ). Fig. 8b (ca $50 \mathrm{Ma}$ ) indicates their relative position during the Middle Eocene. At that time, Timor and Kolonodale blocks were close to the Eurasian margin, while the Lucipara, Seram, Banggai-Sula and Irian Jaya blocks were still attached to the Australian plate. The Halmahera block sat in the southern part of the Pacific plate. 
The paleoposition of the southeast Eurasian plates at $30 \mathrm{Ma}$ (according to Lee and Lawver (1995) modified) is presented in Fig. 9. The Timor and Kolonodale blocks were attached to the Eurasian margin but at that time the Lucipara, Banggai-Sula and Seram blocks were still attached to the Irian Jaya Mobile belt.

At ca $20 \mathrm{Ma}$, the Lucipara block moved away from the Banggai-Sula and Seram blocks (Fig. 7).

At ca 15-13 Ma (Fig. 10), after its collision with Sulawesi-Kolonodale, it moved to the West and pushed the Sulawesi area far away from the Timor block. We suppose that the Lucipara indentation in the Sulawesi block was accommodated by a sinistral strike-slip faulting along the Kalao fault zone, as well as by several thrusts on Sulawesi Island (e.g. Poso thrust). At this time, the Seram and Banggai-Sula blocks approached Lucipara although they were separated from it by a back-arc basin between 20 and $15 \mathrm{Ma}$ (Monnier et al., 2003).

Around $10 \mathrm{Ma}$ ago, Seram probably collided with the Banda ridges (ca 11-10 Ma) and a new back-arc basin, the North Banda basin, opened in front of the Seram block. Then, the Banggai-Sula block moved to the west, pushed by the Halmahera block. The ophiolite "obduction" on Seram and Ambon, between 9 and 7 Ma, could be linked to the Banggai-Sula motion.

Finally the collision between the Australian margin and the Banda area by the Middle Pliocene gathered all these blocks in the restricted eastern Indonesian area. Seram did not move at all, whereas Banggai-Sula shifted to the west, closing the northern part of the North Banda Sea basin (at ca $7 \mathrm{Ma}$ ) and colliding with the northeastern arm of Sulawesi at ca 3.5 Ma. Finally, the northern part of Sulawesi was driven away (to the west) from the Sulawesi south-eastern arm.

To the east, the continental margin of the Bird's Head rallied the Seram accretionary wedge at $5 \mathrm{Ma}$. Its deformation occurred in the northeast of Seram (Selas Formation) during the Early Pliocene.

To the south, the south Banda basin began to open at ca 6.5 Ma, and the elements that had drifted south (e.g. Timor and Tanimbar) began to collide with the Australian margin around 3.5 Ma. The Kolbano unit amalgamated with the southernmost part of the Timor block, and the south Tanimbar unit (Tnb2) was added to the north Tanimbar unit (Tnb1). The northern shift of the Australian plate led, in the Middle Pliocene, to its collision with the Timor block reacting as an indentor, and also led to the opening of the Weber basin ca $3 \mathrm{Ma}$ ago.

The assessment of this amalgamation in an area of 540,000 $\mathrm{km}^{2}$ delimited by Sulawesi and Kai islands on the one hand, and Sula and Timor islands on the other hand, is a cumulated basin surface of $10,4600 \mathrm{~km}^{2}$ with new oceanic type crusts formed between 12 and $3.5 \mathrm{Ma}$. Consequently, the cumulated surface of continental crust in this domain is $435,400 \mathrm{~km}^{2}$, encompassing the Timor, Kolonodale, Seram and Banggai-Sula blocks.

Kinematic studies were also performed in this area ( [Hinschberger et al., 2005] and [Pubellier et al., 2003b] ) but our goal is to estimate the mean displacement rates of each block with respect to the restored maps from Pubellier et al. (2003b). So, we estimate the mean velocity rates to be $12.5 \mathrm{~cm} / \mathrm{y}$ for Halmahera, $15.5 \mathrm{~cm} / \mathrm{y}$ for Lucipara, and $11 \mathrm{~cm} / \mathrm{y}$ for Seram and 
Banggai-Sula. It is to be noticed that, except for the Lucipara block, these rates are similar to the present Pacific plate rate.

\section{Conclusion}

Our geological investigations on the islands of Sulawesi, Seram, Ambon, Timor, Flores, Sumba, Kur, Kai and Irian Jaya and coupled with studies in the adjacent Celebes Sea, Gorontalo gulf, north and south Banda basins, Weber basin and Aru trough marine basins, allow us to have a better understanding of the origin and evolution of the East Indonesian blocks.

We can identify seven blocks in the East Indonesian area. Six are of Gondwanan origin (i.e. Timor, Kolonodale, Lucipara, Seram, Banggai, Sula and Irian Jaya), while only the Halmahera block belongs to the Pacific plate.

The amalgamation of these six Gondwanan blocks with the Eurasian plate was fully dependent on the Pacific and Australian plates' kinematics. At the easternmost boundary of the Alpine system, this amalgamation concerned two different types of blocks.

1) Blocks such as Timor and Kolonodale, which were separated from the north-western margin of Australia during the Jurassic and drifted towards the Eurasian margin with the transit plate (Ricou, 1994). Then, between the Jurassic and the Eocene-Oligocene, the Timor and Kolonodale blocks continued their drifting, following a non linear course implying a straight $\mathrm{S}-\mathrm{N}$ displacement during more or less $100 \mathrm{Ma}$. During the last $30 \mathrm{Ma}$, Timor underwent a reversed $\mathrm{N}-\mathrm{S}$ displacement (from Sulawesi in the north to the North Australian margin in the south).

2) Blocks that were located in the east when the Pacific motion became dominant. Separated in the Late Oligocene to Early Miocene times, they achieved their movement until ca 5-3 Ma ago. Lucipara, Seram and Banggai-Sula blocks were probably separated from the western part of the Papua-New Guinea by strike-slip faulting during the Neogene. For instance, the Seram and Banggai-Sula blocks, separated from each other by an Early Miocene back-arc basin, were probably detached from Irian Jaya during the Early Middle Miocene.

The Irian Jaya block, still attached to the Australian margin at the Neogene, moved along the "Aiduna-Tarera fault" and reached the Seram Island by the Early Pliocene.

It is likely that most of the basins opened in the Late Miocene and, consequently, have had modest consequences on the proposed geodynamic model.

The geodynamic model of block amalgamation, in a triple plate convergent context, is a specific case study, considering the rarity of such space and time complexities on the earth's surface. In fact, the main driving force for this tectonic process is largely dominated by the Pacific plate motion which pushed the blocks from Irian Jaya towards the "Sulawesi wall", provoking later indentations within the East Sulawesi arms ( [Silver et al., 1983] and [Bellier et al., 2006] ). The recent history of openings and reengagements of arcs and marginal basins complicates the distribution of these Gondwanan blocks, even though global changes are 
mainly controlled by the kinematics of just two plates: the Indo-Australian and the Philippine-Pacific plates converging towards Eurasia.

Finally, many changes are expected in the future. Among them, geodetic measurements conducted by different teams ( [Stevens et al., 1993] , [Puntodewo et al., 1994], [Wilson et al., 1998] , [Chamot-Rooke and Le Pichon, 1999] , [Rangin et al., 1999] , [Michel et al., 2001] and [Tregoning, 2002] ) indicate that the active plate convergence will lead, in the next million years, to the complete subduction of the South Banda basin and the squeezing of the whole Banda area.

\section{Acknowledgements}

This large work has benefited from a longstanding cooperation between French and Indonesian geologists, geophysicists and geochemists, partly initiated by the French Indonesian Cooperation in Oceanography agreement and supported by the French Foreign Office and French Embassy together with numerous Indonesian and French Research Institutions: BBPT, MGI, LIPI, ITB, GRDC in Indonesia, and IFREMER, GENAVIR, CNRS, IRD (ORSTOM), Universities of Brest, Pierre and Marie Curie in Paris ,Paris XI at Orsay, Nice Sophia-Antipolis and Provence at Marseille, in France. We hold respectfully in memory of Hubert Curien who always facilitated the smooth running of this program. We also thank Marc Pain, scientific attaché at the French Embassy in Jakarta and our colleague, J.A. Malod, an active participant in numerous cruises and field trips, and all our colleagues. We are thankful to J. Metzger (University of Geneva) for their precious help in computer drafting. This work is partially supported by the Swiss National Science Foundation (R. Martini grant \# 200021-113816). We are indebted to Christopher Marriner, from the Cerege (Aix-en Provence, France) who corrected the English text.

\section{References}

Abdullah et al., 2000 C.I. Abdullah, J.-P. Rampnoux, H. Bellon, R.C. Maury and R. SoeriaAtmadja, The evolution of Sumba Island (Indonesia) revisited in the light of new data on the geochronology and geochemistry of the magmatic rocks. Journal of Asian Earth Sciences, 18 (2000), pp. 533-546.

Abimanyu, 1990 R. Abimanyu, The stratigraphy of the Sulawesi group in the Tomori PSC, East Arm of Sulawesi Proceedings 19th Annual Convention of the Indonesian Association of Geologists (1990), pp. 99-118.

Agustiyanto and Suparman, 1989 Agustiyanto, D.A, Suparman, M., 1989. Geologi lembar Moa, Damar dans bandanaira, Malukku, 1/250 000, Geological Research and Development Centre, internal report..

Ali and Aitchison, 2005 J.R. Ali and J.C. Aitchison, Greater India. Earth-Science Reviews, 72 3-4 (2005), pp. 169-188.

Ali et al., 2001 J.R. Ali, R. Hall and S.J. Baker, Palaeomagnetic data from a Mesozoic Philippine Sea Plate ophiolite on Obi Island, Eastern Indonesia. Journal of Asian Earth Sciences, 19 (2001), pp. 535-546. 
Audley Charles, 1968 M.G. Audley Charles, The geology of Portuguese Timor. Memoir Geological Society London, 4 (1968), pp. 1-76.

Audley-Charles, 1979 M.G. Audley-Charles, The Indonesian and Philippine archipelagos, The Mesozoic, vol. 2 ,in: M. Moullade, A.E.M. Nairn, Editors, The Phanerozoic Geology of the World, Elsevier, Amsterdam (1979), pp. 165-207.

Audley-Charles, 1988 M.G. Audley-Charles, Evolution of the southern margin of Tethys (North Australian region) from Early Permian to Late Cretaceous, Geological Society of London, Special Publication, vol. 37 ,in: M.G. Audley-Charles, A. Hallam, Editors , GondwanaTethys (1988), pp. 79-100

Audley-Charles et al., 1979 M.G. Audley-Charles, D.J. Carter, A.J. Barber, M.S. Norvick and S. Tjokosapoetro, Reinterpretation of the Geology of Seram: implications for the Banda Arcs and northern Australia. Journal of the Geological Society of London, 136 (1979), pp. 547568

Audley-Charles et al., 1988 M.G. Audley-Charles, P.D. Ballantyne and R. Hall, MesozoicCenozoic rift-drift sequence of Asian fragments from Gondwanaland.

Tectonophysics, 155 (1988), pp. 317-330.

Bachri and Situmorang, 1994 S. Bachri and R.L. Situmorang, Geological Research and Development Centre, Bandung, Indonesia geological map of the Dili sheet. East Timor, 1250 (1994), p. 000.

Bailly et al., 2009 V. Bailly, M. Pubellier, J.-C. Ringenbach, J. de Sigoyer and F. Sapin, Deformation zone 'jumps' in a young convergent setting; the Lengguru fold-and-thrust belt, New Guinea Island. Lithos, 113 (2009), pp. 306-317.

Barber and Crow, 2003 A.J. Barber and M.J. Crow, An evaluation of plate tectonic models for the development of Sumatra. Gondwana Research, 6 (2003), pp. 1-28.

Barber et al., 1977 A.J. Barber, M.G. Audley-Charles and D.J. Carter, Thrust tectonics in Timor. Journal of the Geological Society of Australia, 241 (1977), pp. 51-62.

Bellier et al., 2006 O. Bellier, M. Sebrier, D. Seward, T. Beaudouin, M. Villeneuve and E. Putranto, Fission track and faults kinematic analyses for new insights into the Late Cenozoic tectonic regime in West-Central Sulawesi (Indonesia). Tectonophysics, 413 (2006), pp. 201220.

Ben Avraham, 1978 Z. Ben Avraham, The evolution of marginal basins and adjacent shelves in East and Southeast Asia. Tectonophysics, 45 (1978), pp. 269-288.

Bergman et al., 1996 S.C. Bergman, D.Q. Coffield, J.P. Talbot and R.A. Garrard, Tertiary Tectonic and magmatic evolution of western Sulawesi and the Makassar Strait, Indonesia: evidence for a Miocene continent-continent collision, Geological Society of London, Special Publication, vol. 106 , in: R. Hall, D.J. Blundell, Editors, Tectonic Evolution of Southeast Asia (1996), pp. 391-429. 
Bowin et al., 1980 C. Bowin, G.M. Purdy, C. Johnston, G. Shor, L. Lawver, H.M.S. Hartono and P. Jezek, Arc-continent collision in Banda Sea region. American Association of Petroleum Geologists Bulletin, 646 (1980), pp. 868-915.

Bradshaw and Yeung, 1992 Bradshaw, M.T., Yeung, M., 1992. Palaeogeographic Atlas of Australia, Volume 8: Jurassic, Bureau of Mineral Resources, Geology and Geophysics, Australia..

Breen et al., 1989 N.A. Breen, E.A. Silver and S. Roof, The Wetar back-arc thrust belt, Eastern Indonesia: the effect of accretion against an irregularly shaped arc. Tectonics, 81 (1989), pp. 85-98.

Brown et al., 2003 B. Brown, R.D. Muller, H.I.M. Struckmeyer, C. Gaina, H. Stagg and P. Symonds, Formation and evolution of Australian passive margin: implications for locating the boundary between continental and oceanic crust, Geol. Soc. Australia, Spec. Pub. 22 and Geol. Soc. Amer, Spec. Paper, vol. 372 ,in: R.R. Hillis, R.D. Muller, Editors, Evolution and Dynamics of the Australian Plate (2003), pp. 223-243.

Carter et al., 1976 D.J. Carter, M.G. Audley-Charles and A.J. Barber, Stratigraphical analysis of island arc-continental margin collision in Eastern Indonesia. Journal of the Geological Society of London, 132 (1976), pp. 179-198.

Chamot-Rooke and Le Pichon, 1999 N. Chamot-Rooke and X. Le Pichon, GPS determined eastward Sundaland motion with respect to Eurasia confirmed by earthquakes slip vectors at Sunda and Philippine trenches. Earth Planetary Science Letters, 173 (1999), pp. 439-455.

Charlton, 1986 T.R. Charlton, A plate tectonic model of the Eastern Indonesia collision zone. Nature, 319 (1986), pp. 394-396

Charlton, 1996 T.R. Charlton, Correlation of the Salawati and Tomori Basins, Eastern Indonesia: a constraint on left-lateral displacements of the Sorong fault zone, Geological Society of London, Special Publication, vol. 106 ,in: R. Hall, D.J. Blundell, Editors , Tectonic Evolution of Southeast Asia (1996), pp. 465-481.

Charlton, 2000 T.R. Charlton, Tertiary evolution of the Eastern Indonesia collision complex. Journal of Asian Earth Sciences, 18 (2000), pp. 603-631.

Charlton, 2001 T.R. Charlton, Permo-Triassic evolution of Gondwana eastern Indonesia, and the final Mesozoic separation of SE Asia from Australia. Journal of Asian Earth Sciences, 19 (2001), pp. 595-617.

Charlton et al., 1991 T.R. Charlton, S.J. Kaye, H. Samodra and Sardjono, Geology of the Kai Islands: implications for the evolution of the Aru Trough and Weber Basin, Banda Arc, Indonesia. Marine and Petroleum Geology, 8 (1991), pp. 62-69.

Cloke et al., 1999 I.R. Cloke, J. Milsom and D.J.B. Blundell, Implications of gravity data from East Kalimantan and the Makassar Straits: a solution to the origin of the Makassar Straits?. Journal of Asian Earth Sciences, 17 (1999), pp. 61-78. 
Cornée et al., 1994 J.J. Cornée, M. Villeneuve, R. Martini, L. Zaninetti, D. Vachard, B. Vrielynck, W. Gunawan, H. Samodra and L. Sarmili, Une plate-forme carbonatée d'âge Rhétien au centre-est de Sulawesi (région de Kolonodale, Celèbes, Indonésie). Comptes Rendus de l'Académie des Sciences Paris, 3182 (1994), pp. 809-814.

Cornée et al., 1997 J.J. Cornée, M. Villeneuve, J.P. Réhault, Malod, J. Butterlin, P.J. SaintMarc, Lambert B. Tronchetti, D. Michoux, S. Burhanuddin, L. Gil-Capar, G., C. Honthaas, J.P. Saint-Martin and L. Sarmili, Stratigraphic succession of the Australian margin between Kai and Aru Islands (Arafura Sea, Eastern Indonesia) interpreted from Banda Sea II cruise samples. Journal of Southeast Asian Earth Sciences, 15 4-5 (1997), pp. 423-434. है:

Cornée et al., 1998 J.J. Cornée, J. Butterlin, P. Saint-Marc, J.P. Réhault, C. Honthaas, A. Laurenti-Ribaud, C. Chaix, M. Villeneuve and Y. Anantasena, An Early Miocene reefal platform in the Rama Ridge (Banda Sea, Indonesia). Geo-Marine Letters, 18 (1998), pp. 3439.

Cornée et al., 2002 J.J. Cornée, M. Villeneuve, M. Ferrandini, F. Hinschberger, J.A. Malod, K. Matsumaru, A. Ribaud-Laurenti and J.P. Réhault, Oligocene reefal deposits in the Pisang Ridge and the origin of the Lucipara Block (Banda Sea, Eastern Indonesia). Geo-Marine Letters, 22 (2002), pp. 66-74.

Crostella, 1977 A. Crostella, Geosynclines and plate tectonics in the Banda Arcs, Eastern Indonesia. American Association of Petroleum Geologists Bulletin, 6112 (1977), pp. 2063 2081.

Crowhurst et al., 1996 P.V. Crowhurst, K.C. Hill, D.A. Foster and A.P. Benett, Thermochronological and geochemical constraints on the tectonic evolution of northern Papua-New Guinea, Geological Society of London, Special Publication, vol. 106 ,in: R. Hall, D.J. Blundell, Editors , Tectonic Evolution of Southeast Asia (1996), pp. 525-537.

Daly et al., 1991 M.C. Daly, M.A. Cooper, I. Wilson, D.G. Smith and B.G.D. Hooper, Cenozoic plate tectonics and basin evolution in Indonesia, South-East Asia. Marine and Petroleum Geology, 8 (1991), pp. 2-21.

Davidson, 1991 J.W. Davidson, The geology and prospectivity of Buton Island southeast Sulawesi, Indonesia Proceedings 20th Annual Convention, Indonesian Petroleum Association (1991).

Davies, 1990 I.C. Davies, Geological and exploration review of the Tomori PSC, Eastern Indonesia Proceedings of IPA 19th Annual Convention, Jakarta, Proceedings Indonesian Petroleum Association (1990), pp. 41-67.

De Smet, 1989 M.E.M. De Smet, A geometrically consistent plate tectonic model for eastern Indonesia, Netherlands Journal of Sea Research, vol. 24 ,in: J.E. van Hinte, T.C.E. van Weering, A.R. Fortuin, Editors, Proceedings for Snellius II Symposium. Theme; Geology and Geophysics of Banda Arc and Adjacent Areas, Part I (1989), pp. 173-183.

De Smet et al., 1989 M. De Smet, P.A. Sumosuastro, L.J. Siregar, L. van Marle, J., S.R. Troelstra and A.R. Fortuin, Cenozoic geohistory of Seram, Indonesia Geologie en Mijnbouw, Kuwer Academic Publisher, Dordrecht, Netherlands (1989), pp. 221-235. 
Dow and Sukamto, 1984 D.B. Dow and R. Sukamto, Western Irian Jaya: the end-product of oblique plate convergence in the late Tertiary. Tectonophysics, 106 (1984), pp. 109-139.

Dow et al., 1986 Dow, D.B., Robinson, G.B, Hartono, U., Ratman N., 1986. Geological Research and Development Centre, Bandung, Indonesia. Geologic map of Irian Jaya, Indonesia, 1:100,000.

Durocq, 1996 S. Durocq, The Eocene terrestrial mammal from Timor, Indonesia. Geol. Mag., 133 (1996), pp. 763-766.

Fortuin et al., 1988 A.R. Fortuin, M.E.M. De Smet, P.A. Sumosusatro, L.J. van Marle and S.R. Troelstra, Geologie en Mijnbouw, vol. 67 Late Cenozoic Geohistory of NW Buru, Indonesia and Plate Tectonic Implications, Kuwer Academic Publisher, Dordrecht, Netherlands (1988), pp. 91-105

Fortuin et al., 1990 A.R. Fortuin, M.E.M. De Smet, S. Hadiwasastra, L.J. van Marle, S.R. Troelstra and S. Tjokrosapoetro, Late Cenozoic sedimentary and tectonic history of south Buton, Indonesia. Journal of Southeast Asian Earth Sciences, 42 (1990), pp. 107-124.

Fullerton et al., 1989 S.G. Fullerton, W.W. Sager and D.W. Handschumacher, Late JurassicEarly Cretaceous evolution of the Eastern Indian Ocean adjacent to North-West Australia. Journal of Geophysical Research, 94b (1989), pp. 2937-2953.

Gageonnet and Lemoine, 1958 Gageonnet, R., Lemoine, M., 1958.Contribution à la connaissance de la géologie de la province portuguaise de Timor, Estudos Ensaios Documentos Junta Invest. Ultramar, Lisboa, 48, 1-136..

Garrard et al., 1988 R.A. Garrard, J.B. Supandjono and Surono, The geology of the BanggaiSula microcontinent, Eastern Indonesia IPA 17th Annual Conv., Jakarta, Proceedings of the Indonesian Petroleum Association (1988), pp. 23-52.

Gunawan, 1999 W. Gunawan, Structure, Stratigraphie et Evolution de la Partie Centrale de Sulawesi (Indonésie Orientale), Thèse Université de Marseille, France (1999).

Hailé, 1978 Hailé, Paleomagnetic evidence for the rotation of Seram, Indonesia. Journal of the Physical Earth, 26 (1978), pp. 191-198.

Hall, 1996 R. Hall, Reconstructing Cenozoic SE Asia, Geological Society of London, Special Publication, vol. 106 , in: R. Hall, D.J. Blundell, Editors, Tectonic Evolution of Southeast Asia (1996), pp. 153-184

Hall and Nichols, 1990 R. Hall and G.J. Nichols, Terrane Amalgamation in the Philippine Sea Margin. Tectonophysics, 181 1-4 (1990), pp. 207-222.

Hall et al., 1995 R. Hall, J.R. Ali, C.D. Anderson and S.J. Baker, Origin and motion history of the Philippine Sea Plate: evidence from eastern Indonesia. Tectonophysics, 251 (1995), pp. $229-250$.

Hamilton, 1979 Hamilton, W., 1979. Tectonics of the Indonesian Region. U.S. Geological Survey Professional Paper 1078. 
Handiwiria, 1990 Y.E. Handiwiria, The stratigraphy and hydrocarbon occurrences of the Salodik group, Tomori PSC area Proceedings 19th annual Convention of the Indonesian Association of Geologists (1990).

Harris, 1991 R.A. Harris, Temporal distribution of strain in the active Banda orogen: a reconciliation of rival hypothesis. Journal of Southern Asian Earth Sciences, 6 3-4 (1991), pp. 373-386.

Harris et al., 2000 R.A. Harris, J. Kaiser, A. Hurford and A. Carter, Thermal history of Australian passive margin cover sequences accreted to Timor during Late Neogene arccontinent collision, Indonesia. Journal of Asian Earth Sciences, 18 (2000), pp. 47-69.

Harris, 2006 R.A. Harris, Rise and fall of the Eastern Great Indonesian arc recorded by the assembly, dispersion and accretion of the Banda Terrane, Timor. Gondwana Research, $103-$ 4 (2006), pp. 207-231.

Harrowfield and Keep, 2005 M. Harrowfield and M. Keep, Tectonic modification of the Australian North-West Shelf: episodic rejuvenation of long-lived basin divisions. Basin Research, 17 (2005), pp. 225-239.

Harsolumakso, 1993 Harsolumakso, A.H., 1993. Etude lithostratigraphique et structurale le long du transect Wini-Kolbano, à Timor Ouest (Indonésie). Thèse, Université de NiceSophia-Antipolis, Valbonne, France..

Hasan, 1990 Hasan, K., 1990. The Upper Cretaceous flysch succession of the Balangbaru formation, Southwest Sulawesi, Indonesia, Thesis, University of London..

Heine et al., 2004 C. Heine, R.D. Muller and C. Gaina, Reconstructing the Lost Eastern Tethys Ocean Basin: convergence history of the Southeast Asian margin and marine gateways, $A G U$ monograph, vol. 149 ,in: P.D. Clift, P. Wang, W. Khunt, D.E. Hayes, Editors , Continent-ocean interactions within the East Asia marginal seas (2004), pp. 37-54.

Helmers et al., 1989 H. Helmers, J. Sopaheluwakan, E. Surya-Nila and S. Tjokosapoetro, Blueschists evolution in southeast Sulawesi, Indonesia. Netherlands Journal of Sea Research, 24 2-3 (1989), pp. 373-381.

Hill and Hall, 2002 K.C. Hill and R. Hall, Mesozoic-Cainozoic evolution of Australia's New Guinea margin in a West Pacific context, Geological Society of America and Geological Society of Australia, joint publication, special paper, ,in: R. Hillis, R.D. Muller, Editors, Defining Australia: the Australian Plate as Part of Planet Earth (2002), pp. 1-43.

Hinschberger et al., 2000 F. Hinschberger, J.A. Malod, J.P. Réhault, J. Dyment, C. Honthaas, M. Villeneuve and S. Burhanuddin, Origine et évolution du Bassin Nord Banda (Indonésie): apport des données magnétiques. Comptes Rendus Académie des Sciences Paris, 331 (2000), pp. 507-514.

Hinschberger et al., 2001 F. Hinschberger, J.A. Malod, J. Dyment, C. Honthaas, J.P. Réhault and S. Burhanuddin, Magnetic lineation constraints for the back-arc opening of the Late Neogene South Banda Basin (Eastern Indonesia). Tectonophysics, 333 (2001), pp. 47-59. 
Hinschberger et al., 2005 F. Hinschberger, J.A. Malod, J.P. Rehault, M. Villeneuve, J.Y. Royer and S. Burhanuddin, Late Cenozoic geodynamic evolution of eastern Indonesia. Tectonophysics, 404 1-2 (2005), pp. 91-118.

Hinz et al., 1978 K. Hinz, H. Beiersdorf, N.F. Exon, A. Roeser, H.M.J. Stagg and U. Von Stackelberg, Geoscientific investigations from the Scott plateau off northwest Australia to the Java trench. BMR, Journ of Australian Geology \& Geophysics, 3 (1978), pp. 319-340.

Honthaas et al., 1997 C. Honthaas, M. Villeneuve, J.P. Réhault, H. Bellon, J.J. Cornée, P. Saint-Marc, J. Butterlin, M. Gravelle and S. Burhanuddin, L'île de Kur: géologie du flanc oriental du bassin de Weber (Indonésie orientale). Comptes Rendus Académie des Sciences Paris, 325 (1997), pp. 883-890.

Honthaas et al., 1998 C. Honthaas, J.P. Réhault, R.C. Maury, H. Bellon, C. Hémond, J.A. Malod, J.J. Cornée, M. Villeneuve, J. Cotten, S. Burhanuddin, H. Guillou and N. Arnaud, A Neogene back-arc origin for the Banda Sea basins: geochemical and geochronological constraints from the Banda ridges (East Indonesia). Tectonophysics, 298 (1998), pp. 297317.

Honthaas et al., 1999 C. Honthaas, R.C. Maury, B. Priadi, H. Bellon and J. Cotten, The PlioQuaternary Ambon arc, Eastern Indonesia. Tectonophysics, 301 (1999), pp. 261-281.

Honza and Fujuoka, 2004 E. Honza and K. Fujuoka, Formation of arcs and back-arc basins inferred from the tectonic evolutions of Southeast Asia since the late Cretaceous.

Tectonophysics, 384 (2004), pp. 23-53.

Ishikawa et al., 2007 A. Ishikawa, Y. Kaneko, A. Kadarusman and T. Ota, Multiple generations of fore-arc mafic-ultramafic rocks in the Timor-Tanimbar ophiolite, Eastern Indonesia. Gondwana Research, 11 1-2 (2007), pp. 200-217.

Jasin and Hailé, 1996 B. Jasin and N. Hailé, Uppermost Jurassic-Lower Cretaceous radiolarian chert from the Tanimbar Islands (Banda Arc), Indonesia. Journal of Southeast Asian Earth Sciences, 14 1-2 (1996), pp. 91-100.

Jeffrey et al., 1996 F.A. Jeffrey, Malaihollo and R. Hall, The geology and tectonic evolution of the Bacan region, East Indonesia, Geological Society of London, Special Publication, vol. 106 ,in: R. Hall, D.J. Blundell, Editors, Tectonic Evolution of Southeast Asia (1996), pp. 483-497.

Kadarusman et al., 2004 A. Kadarusman, S. Miyashita, S. Maruyama, C. Parkinson and A. Ishakaw, Petrology, geochemistry and paleogeographic reconstruction of the East Sulawesi Ophiolite, Indonesia. Tectonophysics, 392 1-4 (2004), pp. 55-83.

Kaneko et al., 2007 Y. Kaneko, S. Maruyama, A. Kadarusman, T. Ota, M. Ishikawa, T. Tsujimori, A. Ishikawa and K. Okamoto, Multiple generations of fore-arc mafic-ultramafic rocks in the Timor-Tanimbar ophiolite, Eastern Indonesia. Gondwana Research, 11 1-2 (2007), pp. 200-217.

Katili, 1975 J.A. Katili, Volcanism and plate tectonics in the Indonesian island arcs. Tectonophysics, 26 (1975), pp. 165-188. 
Kundig, 1956 E. Kundig, Geology and ophiolite problems of East Sulawesi. Verhage Kononklij Nederland Geologishe. Minjbown Genootshaf Geologishe, 16 (1956), pp. 210 235.

Lapouille et al., 1985 A. Lapouille, H. Haryono, M. Laure, S. Pramumijoyo and M. Lardy, Age and origin of the seafloor of the Banda Sea (eastern Indonesia). Oceanologica Acta, 8 (1985), pp. 379-389.

Lee and Lawver, 1995 T.Y. Lee and L.A. Lawver, Cenozoic plate reconstruction of Southeast Asia. Tectonophysics, 251 (1995), pp. 85-138.

Letouzey et al., 1983 J. Letouzey, P. de Clarens, J. Guignard and J.L. Berthon, Structure of the north Banda-Molucca area from multichannel seismic reflection data IPA 12th Annual Convention, Jakarta, Proceedings of Indonesian Petroleum Association (1983), pp. 143-156.

Li and Powell, 2001 Z.X. Li and C.McA Powell, An outline of the paleogeographic evolution of Australian region since the beginning of the Neoproterozoic. Earth Science Review, 53 (2001), pp. 237-277.

Linthout and Helmers, 1994 K. Linthout and H. Helmers, Pliocene obducted rotated and migrated ultramafic rocks and obduction-induced anatectic granite, SW Seram and Ambon, Eastern Indonesia. Journal of Southeast Asian Earth Sciences, 9 (1994), pp. 95-109.

Linthout et al., 1989 K. Linthout, H. Helmers, J. Sopaheluwakan and E. Surya-Nila, Metamorphic complexes in Buru and Seram, northern Banda arc. Netherlands Journal of sea Research, 24 2-3 (1989), pp. 345-356.

Linthout et al., 1991 K. Linthout, H. Helmers and P.A.M. Andriessen, Dextral strike slip in Central Seram and 3-4.5 Ma Rb/Sr ages in the pre-Triassic metamorphics related to the Early Pliocene clockwise rotation of the Buru Seram microplate (E. Indonesia). Journal of Southeast Asian Earth Sciences, 6 (1991), pp. 335-342.

Linthout et al., 1996 K. Linthout, H. Helmers, J.R. Wijbrans, J. Diederik and V. Vess, 40Ar/39Ar constraints on obduction of Seram ultramafic complex: consequences for the evolution of the southern Banda Sea, Geological Society of London Special Publication, vol. 106 ,in: R. Hall, D.J. Blundell, Editors, Tectonic Evolution of Southeast Asia (1996), pp. 455-464.

Linthout et al., 1997 K. Linthout, H. Helmers and J. Sopaheluwakan, Late Miocene obduction and microplate migration around the southern Banda Sea and closure of the Indonesian Seaway. Tectonophysics, 281 (1997), pp. 17-30.

Ludbrook, 1978 N.H. Ludbrook, Australia, M. Moullade, A.E.M. Nairn, Editors, The Phanerozoic geology of the World II: the Mesozoic, Elsevier (1978), pp. 209-249.

Martini et al., 1997 R. Martini, D. Vachard, L. Zaninetti, S. Cirilli, J.J. Cornée, B. Lathuilliere and M. Villeneuve, Sedimentology, stratigraphy and micropaleontology of the Upper Triassic reefal series in Eastern Sulawesi (Indonesia). Palaeogeography, Palaeoclimatology, Palaeoecology, 128 (1997), pp. 157-174. 
Martini et al., 2000 R. Martini, L. Zaninetti, M. Villeneuve, J.J. Cornée, L. Krystin, S. Cirilli, P. De Wever, P. Dumetrica and A. Harsolumakso, Triassic pelagic deposits of Timor: palaeogeographic and sea-level implications. Palaeogeography, Palaeoclimatology, Palaeoecology, 160 (2000), pp. 123-151.

Martini et al., 2004 R. Martini, L. Zaninetti, B. Lathuilliere, S. Cirilli, J.J. Cornée and M. Villeneuve, Upper Triassic carbonates deposits of Seram (Indonesia): palaeogeographic and geodynamic implications. Palaeogeography, Palaeoclimatology,

Palaeoecology, 206 (2004), pp. 75-102.

Meert and Lieberman, 2008 J.G. Meert and B.S. Lieberman, The Neoproterozoic assembly of Gondwana and its relationship to the Ediacaran-Cambrian radiation. Gondwana Research, 14 (2008), pp. 5-21.

Melleton et al., 2010 J. Melleton, A. Cocherie, M. Faure and P. Rossi, Precambrian protoliths and Early Paleozoic magmatism in the French Massif Central: U-Pb data and the North Gondwana connection in the west European Variscan belt. Gondwana Research, 17 (2010), pp. 13-25.

Metcalfe, 1993 I. Metcalfe, Southeast Asian terranes: Gondwanaland origins and evolution, R.H. Findlay, R. Unrug, M.R. Banks, J.J. Veevers, Editors, Gondwana Eight: Assembly, Evolution and Dispersal, Balkema, Rotterdam (1993), pp. 181-200.

Metcalfe, 2006 I. Metcalfe, Palaeozoic and Mesozoic tectonic evolution and palaeogeography of East Asian crustal fragments: the Korean Peninsula in context. Gondwana Research, 9 (2006), pp. 24-46.

Michel et al., 2001 G.W. Michel, Q.Y. Yue, S.Y. Zhu, C. Reigber, M. Becker, E. Reinhart, W. Simons, B. Ambrosius, C. Vigny, N. Chamot-Rooke, X. Le Pichon, P. Morgan and S. Matheussen, Crustal motion and block behaviour in SE-Asia from GPS measurements. Earth Planetary Science Letters, 187 (2001), pp. 239-244.

Miyazaki et al., 1996 K. Miyazaki, I. Zulkarnain, J. Sopaheluwakan and K. Wakita, Pressuretemperature conditions and retrograde paths of eclogites, garnet-glaucophane rocks and schists from South Sulawesi, Indonesia. Journal of Metamorphic Geology, 14 (1996), pp. $549-563$.

Monnier, 1996 Monnier, C., 1996. Mécanismes d'accrétion des domaines océaniques arrièrearc et géodynamique de l'Asie du Sud-Est. Pétrologie et géochimie des ophiolites d'Indonésie (Sulawesi, Haute-Chaîne Centrale, Cyclops, Seram et Meratus). Thèse de Doctorat, Université de Brest, France.

Monnier et al., 1994 C. Monnier, H. Bellon and J. Girardeau, Datation ${ }^{40} \mathrm{~K} /{ }^{40} \mathrm{Ar}$ de l'ophiolite de l'île de Sulawesi Comptes Rendus de l'Académie des Sciences Paris, t. 319, série II (1994), pp. 349-356.

Monnier et al., 1995 C. Monnier, J. Girardeau, R.C. Maury and J. Cotton, Back-arc origin for the East Sulawesi Ophiolite (Indonesia). Geology, 239 (1995), pp. 851-854. 
Monnier et al., 1999 C. Monnier, J. Girardeau, M. Pubellier, M. Polvé, H. Permana and H. Bellon, Petrology and geochemistry of the Cyclops ophiolite (Irian Jaya, East Indonesia), consequences for the evolution of the north Australian margin during Cainozoic. J. Mineral. Petrol., 65 (1999), pp. 1-28.

Monnier et al., 2003 C. Monnier, J. Girardeau, J.-P. Réhault, H. Permana and H. Bellon, Dynamics and age of formation of the Seram-Ambon ophiolites (Central Indonesia). Bulletin de la Société géologique de France, 174 (2003), pp. 529-543

Mubroto et al., 1994 B. Mubroto, C. Briden, A. McClelland and R. Hall, Paleomagnetism of the Balantak ophiolite, Sulawesi. Earth and Planetary Science Letters, 125 (1994), pp. 193 209.

Murphy et al., 2009 J.B. Murphy, R.D. Nance and P.A. Cawood, Contrasting modes of supercontinent formation and the conundrum of Pangea. Gondwana Research, 15 (2009), pp. $408-420$.

Nichols and Hall, 1999 G. Nichols and R. Hall, History of the Celebes Sea Basin based on its stratigraphic and sedimentological record. Journal of Asian Earth Sciences, 17 (1999), pp. 47-59.

O'Sullivan et al., 1985 T. O'Sullivan, D. Pegun and J. Tarignan, Seram oil search, past discovery and future oil potential Indonesian Petroleum Association Proceedings, 14th annual convention, Jakarta (1985), pp. 3-19.

Parkinson, 1991 Parkinson, C.D., 1991. The petrology, structure and geologic history of the metamorphics rocks of central Sulawesi, Indonesia. Thesis, University of London..

Parkinson, 1996 C.D. Parkinson, The origin and significance of metamorphosed tectonic block in melanges: evidence from Sulawesi, Indonesia. Terra Nova, 8 (1996), pp. 312-323.

Parkinson, 1998 C.D. Parkinson, Emplacement of the East Sulawesi Ophiolite: evidence from sub-ophiolite metamorphic rocks. Journal of Asian Earth Sciences, 16 (1998), pp. 13-28.

Permana, 1995 Permana, H., 1995. Etude des ophiolites des Weylands (Irian Jaya): origine et âge de mise en place. Comparaison avec celles de la Haute Chaîne centrale. Mémoire DEA, Université de Brest, France..

Petkovic et al., 2000 P. Petkovic, C.D.N. Collins and D.M. Finlayson, A crustal transect between Precambrien Australia and the Timor Trough across the Vulcan sub-basin.

Tectonophysics, 329 (2000), pp. 23-38.

Pigram et al., 1982 C.J. Pigram, A.B. Challinor, F. Hasibuan, E. Rusmana and U. Hartono, Geological results of the 1981 expedition to the Misool archipelago, Irian Jaya. Geological Research and Development Centre Bulletin, 6 (1982), pp. 18-29.

Pigram et al., 1984 C.J. Pigram, Surono and J.B. Supandjono, Geology and Regional Significance of the Sula Platform, East Indonesia. Joint Publication by Geol Geological Research and Development Centre, Indonesia and Bureau of Mineral Resources Australia, (1984). 
Pigram et al., 1985 C.J. Pigram, Surono and J.B. Supandjono, Origin of the Sula Platform, Eastern Indonesia. Geology, 13 (1985), pp. 246-248.

Priadi, 1993 Priadi, B., 1993. Géochimie du magmatisme de l'Ouest et du Nord de Sulawesi, Indonésie : traçage des sources et implications géodynamiques, Thèse, Université Paul Sabatier, Toulouse, France..

Prouteau, 1995 Prouteau, G., 1995. Contribiution à l'étude pétrologique, géochimique et géochronologique du magmatisme post-collisionnel de l'Irian Jaya, DEA Memoir, University of Western Brittany, 48 p..

Pubellier and Ego, 2002 M. Pubellier and F. Ego, Anatomy of an escape tectonic zone: Western Irian Jaya (Indonesia). Tectonics, 214 (2002), p. 1019.

Pubellier et al., 1998 M. Pubellier, J. Girardeau and I. Tjashuri, Accretion history of Borneo inferred from the polyphase structural features in the Meratus Mountains, Final results from IGCP 321, ,in: I. Metcalfe, Editor, Gondwana Dispersion and Asian Accretion, AA Belkema publishers, Rotterdam (1998), pp. 141-160.

Pubellier et al., 2003a M. Pubellier, J. Ali and C. Monnier, Cenozoic plate interaction of the Australia and Philippine Sea plates: "hit-and-run" tectonics. Tectonophysics, 363 (2003), pp. 181-199.

Pubellier et al., 2003b M. Pubellier, F. Ego, N. Chamot-Rooke and C. Rangin, The building of pericratonic mountain ranges: structural and kinematic constraints applied to GIS-based reconstructions of SE Asia. Bulletin Société géologique de France, 1746 (2003), pp. 561584

Pubellier et al., 2004 M. Pubellier, C. Monnier, R. Maury and R. Tamayo, Plate kinematics, origin and tectonic emplacement of supra-subduction ophiolites in SE Asia.

Tectonophysics, 392 1-4 (2004), pp. 9-36

Puntodewo et al., 1994 S.S.O. Puntodewo, R. Mc Caffrey, E. Calais, Y. Bock, J. Rais, C. Subarya, R. Poeweriardi, C. Stevens, J. Genrich, P. Fauzi, P. Zwick and S. Wdowinski, GPS measurements of crustal deformation within the Pacific-Australia plate boundary zone in Irian Jaya, Indonesia. Tectonophysics, 237 (1994), pp. 141-153.

Rangin et al., 1990 and the Thethys Pacific working group, C. Rangin, L. Jolivet and M. Pubellier, A simple model for the tectonic evolution of southeast Asia and Indonesia region for the past 43 m.y. Bulletin de la Société géologique de France, 86 (1990), pp. 889-905.

Rangin et al., 1995 C. Rangin, E.A. Silver and K. Tamaki, Closure of Western Pacific marginal basins: rupture of the oceanic crust and the emplacement of ophiolites, Active Margins and Marginal basins of the Western Pacific, American Physical Union, Geophysical Monography, vol. 88 (1995), pp. 405-417.

Rangin et al., 1999 C. Rangin, X. Le Pichon, S. Mazzotti, M. Pubellier, N. Chamot-Rooke, M. Aurelio, A. Walpersdorf and R. Quebral, Plate convergence measured by GPS across the Sundaland/Philippine Sea Plate deformed boundary: the Philippines and Eastern Indonesia. Geophysical Journal of the Interior, 139 (1999), pp. 296-316. 
Réhault et al., 1994 J.P. Réhault, R.C. Maury, H. Bellon, L. Sarmili, S. Burhanuddin, J.L. Joron, J. Cotten and J.A. Malod, La Mer de Banda Nord (Indonésie): un bassin arrière-arc du Miocène supérieur. Comptes Rendus de l'Académie des Sciences Paris, 318 (1994), pp. 969976.

Ricou, 1994 L.E. Ricou, Tethys reconstructed: plates, continental fragments and their boundaries since $260 \mathrm{Ma}$ from Central America to South-Eastern Asia. Geodinamica Acta, 7 (1994), pp. 169-218.

Rosidi et al., 1987 Rosidi, H.M.D., Suwitodirdjo, K., Tjokosopoetro, S., 1987. Geological Research and Development Centre, Bandung, Indonesia, Geological map of Kupang-Atambua quadrangle, Timor, 1:250,000..

Rusmana et al., 1993a E. Rusmana, A. Koswara and T.O. Simanjuntak, Geological Research and Development Centre, Bandung, Indonesia, geology of the Luwuk sheet. Sulawesi, 1250 (1993), p. 000.

Rusmana et al., 1993b Rusmana, E., Sukido, Sukarna, D., Haryanto, E., Simanjuntak, T.O., 1993b. Geological Research and Development Centre, Bandung, Indonesia. Geology of the Lasusua-Kendari quadrangle, Sulawesi, 1:250,000..

Ryacudu et al., 1993 R. Ryacudu, T. Wibodo and Y.E. Handiwira, Exploration for carbonates reservoirs in the Banggai-Sula microcontinent, Eastern Indonesia Proceed. of Indon. Petrol. Asso, 22nd Annual Convention, Jakarta (1993), pp. 679-692.

Sager et al., 1992 W.W. Sager, L.G. Fullerton, R.T. Buffler and D.W. Handschumacher, Argo abyssal plain magnetic lineations revisited: implications for the onset of seafloor spreading and tectonic evolution of the eastern Indian Ocean. Proceedings Ocean Drilling Project, Scientific Results, 123 (1992), pp. 659-669.

Santosh et al., 2009 M. Santosh, S. Maruyama and S. Yamamoto, The making and breaking of supercontinents: some speculations based on superplumes, super downwelling and the role of tectosphere. Gondwana Research, 15 (2009), pp. 324-341.

Sapie and Cloos, 2004 B. Sapie and M. Cloos, Strike-slip faulting in the core of Central range of west New Guinea: Ertsberg Mining District, Indonesia. Geological Society of America Bulletin, 116 3-4 (2004), pp. 277-293.

Sawyer et al., 1993 R.K. Sawyer, K. Sani and S. Brown, Stratigraphy and sedimentology of West Timor, Indonesia Proceedings Indonesian Petroleum Association, Jakarta (1993), pp. 534-574.

Scotese and Denham, 1987 Scotese, C.R., Denham, C.R., 1987. User's guide to Terra Mobilis: a plate tectonics program for the Macintosh, Earth in Motion Technologies, Houston..

Scotese et al., 1979 R. Scotese, R.K. Bambach, C. Barton, R. van der Voo and A.M. Ziegler, Palaeozoic base maps. Journal of Geology, 87 (1979), pp. 217-277.

Shashida et al., 1999 K. Shashida, Munasri, S. Adachi and Y. Kamata, Middle Jurassic radiolarian faun from Rotti Island. Journal of Asian Earth Sciences, 17 (1999), pp. 561-572. 
Sikumbang and Sanyoto, 1985 Sikumbang, N., Sanyoto, P., 1985. Geological Research and Development Centre, Bandung, Indonesia. Preliminary geological map of Buton and Muna quadrangles, South Sulawesi. 1:250,000..

Silver and Moore, 1978 E.A. Silver and J.C. Moore, The Molucca Sea collision zone, Indonesia. Journal of Geophysical Research, 83 B4 (1978), pp. 1681-1691.

Silver et al., 1983 E.A. Silver, R. McCaffrey and R.B. Smith, Collision, rotation, and the initiation of subduction in the evolution of Sulawesi, Indonesia. Journal of Geophysical Research, 88 B11 (1983), pp. 9407-9418.

Silver et al., 1985 E.A. Silver, J.B. Gill, D. Schwartz, H. Prasetyo and R.A. Duncan, Evidence for a submerged and displaced continental borderland, north Banda Sea, Indonesia.

Geology, 13 (1985), pp. 687-691.

Silver et al., 1986 E.A. Silver, N. Breen and H. Prasetyo, Multibeam study of the Flores back arc thrust belt (Indonesia). Journal of Geophysical Research, 9133 (1986), pp. 3489-3500.

Simanjuntak, 1986 Simanjuntak, T.O., 1986. Sedimentology and tectonics of the collision complex in the East arm of Sulawesi, Thesis, University of London..

Simanjuntak et al., 1994 Simanjuntak, T.O., Surono, Sukido, 1994. Geological Research and Development Centre, Bandung, Indonesia. The geology of the Kolaka sheet, Sulawesi. 1:250, 000 .

Situmorang, 1992 Situmorang, M., 1992. Sedimentology and marine geology of the Banda arc, Eastern Indonesia. Thesis, University of Utrecht, Netherlands.

Smith, 1985 Smith, R.B., 1985. Sedimentology and tectonics of Miocene collision complex and overlying late orogenic clastic strata. Buton Island, Eastern Indonesia. Ph.D. Thesis, University of California, Santa Cruz..

Smith and Silver, 1991 R.B. Smith and E.A. Silver, Geology of a Miocene collision complex, Buton, Eastern Indonesia. Geological Society of America Bulletin, 103 (1991), pp. 660-678.

Snyder et al., 1996 D.B. Snyder, J. Milsom and H. Prasetyo, Geophysical evidence for local indentor tectonics in the Banda arc east of Timor, Geological Society of London, Special Publication, vol. 106 ,in: R. Hall, D.J. Blundell, Editors, Tectonic Evolution of Southeast Asia (1996), pp. 61-73.

Sopaheluwakan, 1979 J. Sopaheluwakan, The evolution of Franciscan type melange in South Sulawesi, with special reference to the Barru area, Riset, Bandung. Indonesia, J2 1 (1979), pp. $45-54$.

Sopaheluwakan, 1990 Sopaheluwakan, J., 1990. Ophiolite obduction in the Mutis complex, Timor, Eastern Indonesia, PhD. thesis, Vrije Universiteit, Amsterdam, V.U. University Press..

Stevens et al., 1993 C. Stevens, R. Mc Caffrey, Y. Bock, J. Genrich, E. Calais, S. Wdowinski, J. Rais, S.S.O. Puntodewo, C. Subarya, R. Poeweriardi, F. Brunner, P. Tregoning, P. Fauzi 
and P. Zwick, GPS measurements in Indonesia and preliminary results. EOS transactions American Geophysical Union, 74 (1993), p. 108.

Struckmeyer et al., 1993 H.I.M. Struckmeyer, M. Yeung and C.J. Pigram, Mesozoic to Cainozoic plate tectonic and paleogeographic evolution of the New Guinea Region 2nd PNG Petroleum Convention, Port Moresby, Proceedings (1993), pp. 261-290.

Sukamto, 1975 R. Sukamto, The structure of Sulawesi in the light of plate tectonics, Processing Regional Conference Geological and Mineral Resources SE Asia. Jakarta, Indonesian Association of Geologists, 2 (1975), pp. 120-141.

Sukamto, 1982 Sukamto, R., 1982. Geological Research and Development Centre, Bandung, Indonesia. The Geology of Pangkajene and western part of Watampone quadrangle, Sulawesi, $1: 250,000$.

Supandjono and Haryono, 1986 Supandjono, J.B., Haryono, E., 1986. Geological Research and Development Centre report. Laporan Geologi Lembar Banggai Sulawesi-Maluku, Sekala $1: 250,000$.

Surmont et al., 1994 J. Surmont, C. Laj, C. Kissel, C. Rangin, H. Bellon and B. Priadi, New paleomagnetic constraints on the Cenozoic tectonic evolution of the North arm of Sulawesi, Indonesia. Earth Planetary Science Letters, 121 (1994), pp. 629-638.

Surono, 1994 Surono, 1994. A sedimentological investigation of Southeast Sulawesi, Indonesia, with special reference to the Kendari area, Thesis, University of Wollongong, New South Wales, Australia..

Tjokosapoetro and Budhitrisna 1982 S. Tjokosapoetro and T. Budhitrisna, Geology and tectonics of the Northern Banda arc. Bulletin of the Geological Research Centre, Bandung (Indonesia), 6 (1982), pp. 1-17.

Tregoning, 2002 P. Tregoning, Plate kinematics in the western Pacific derived from geodetic observations, . Journal of Geophysical Research, 107 B1 (2002), p. 2020 ECV 7-1 to ECV 78 .

Van Bemmelen, 1949 R.W. Van Bemmelen, The Geology of Indonesia, Government Printing Office, The Hague (1949), 997 pp..

Van der Werff, 1995 W. Van der Werff, The evolution of the Savu Forearc Basin, Indonesia (forearc response to arc/continent collision). Marine Petroleum Geology, 123 (1995), pp. $247-262$.

Van Leeuven, 1981 T.M. Van Leeuven, The geology of southwest Sulawesi with special reference to the Biru area, Geological Research Development Centre, Bandung, Indonesia, Special Publication, vol. 2 , in: A.J. Barber, S. Wiryosudjono, Editors, The Geology and Tectonics of Eastern Indonesia (1981), pp. 277-304.

Van Marle, 1991 L.J. Van Marle, Late Cenozoic paleobathymetry and geohistory analysis of central West Timor, Eastern Indonesia. Marine Petroleum Geology, 8 (1991), pp. 22-34. 
Veevers and Cotterill, 1978 J.J. Veevers and D. Cotterill, Western margin of Australia: evolution of a rifted arch system. Geological Society of America Bulletin, 89 (1978), pp. 337-355

Veevers, 2006 J.J. Veevers, Updated Gondwana (Permian-Cretaceous) earth history of Australia. Gondwana Research, 93 (2006), pp. 231-260.

Villeneuve et al., 1994 M. Villeneuve, J.J. Cornée, R. Martini, L. Zaninetti, J.P. Rehault, S. Burhanudin and J. Malod, Upper Triassic shallow water limestones in the Sinta Ridge (Banda Sea, Indonesia). Geo-Marine Letters, 14 (1994), pp. 29-35

Villeneuve et al., 1998 and the Geobanda group, M. Villeneuve, J.P. Réhault, J.J. Cornée, C. Honthaas and W. Gunawan, Evolution géodynamique de l'Indonésie orientale, de l'Eocène au Pliocène. Comptes Rendus de l'Académie des Sciences Paris, 327 (1998), pp. 291-302.

Villeneuve et al., 1999 M. Villeneuve, A. Harsolumakso, J.J. Cornée and H. Bellon, Structure of West Timor (Eastern Indonesia) along a North-South cross-section. Géologie Méditerranéenne, 26 (1999), pp. 127-142

Villeneuve et al., 2000 M. Villeneuve, J.J. Cornée, W. Gunawan, M.C. Janin, J. Butterlin, P. Saint-Marc and H. Samodra, Continental block collision in the eastern arm of Sulawesi (Indonesia). Structure and geodynamic interpretation. Comptes Rendus de l'Académie des Sciences, Paris, 330 (2000), pp. 371-378.

Villeneuve et al., 2001 M. Villeneuve, J.J. Cornée, W. Gunawan, R. Martini, G. Tronchetti, M.C. Janin, P. Saint-Marc and L. Zaninetti, La succession lithostratigraphique du bloc de Banda dans la région de Kolonodale (Sulawesi central, Indonésie). Bulletin de la Société géologique de France, 1721 (2001), pp. 59-68.

Villeneuve et al., 2002 M. Villeneuve, W. Gunawan, J.J. Cornee and O. Vidal, Geology of the central Sulawesi belt (Eastern Indonesia): constraints for geodynamic models. Internal Journal of Earth Sciences, 91 (2002), pp. 524-537.

Villeneuve et al., 2004 M. Villeneuve, J.J. Cornée, R. Martini and L. Zaninetti, Nouvelle hypothèse sur l'origine des formations géologiques de l'ile de Timor (Sud-Est Asiatique). Comptes Rendus Géosciences Paris, 336 (2004), pp. 1511-1520.

Villeneuve et al., 2005 M. Villeneuve, J.J. Cornée, A.H. Harsolumakso, R. Martini and L. Zaninetti, Revision stratigraphique de l'Ile de Timor (Indonésie orientale). Eclogae geologica Helvetica, 98 (2005), pp. 297-310.

Von Rad and Exon, 1983 U. Von Rad and N.F. Exon, Mesozoic-Cenozoic sedimentary and volcanic evolution of the starved passive margin off northwest Australia. American Association of Petroleum Geologists, 34 (1983), pp. 253-281.

Von Rad et al., 1989 U. Von Rad, J. Thurow, B.U. Haq, F. Gradstein and J. Ludden, Triassic to Cenozoic evolution of the NW Australian margin and the birth of the Indian Ocean (Preliminary results of ODP legs 122 and 123). Geologische Rundschau, 783 (1989), pp. 1189-1210. 
Vroon et al., 1993 P.Z. Vroon, M.J. van Bergen, W.M. White and J.C. Varekamp, Sr-Nd-Pb isotope systematics of the Banda Arc, Indonesia: combined subduction and assimilation of continental material. Journal of Geophysical Research, 9822 (1993), pp. 22349-22366.

Vroon et al., 1996 P.Z. Vroon, M.J. van Bergen and E.J. Forde, Pb and Nd isotope constraints on the provenance of tectonically dispersed continental fragments in east Indonesia, Geological Society of London, Special Publication, vol. 106 ,in: R. Hall, D.J. Blundell, Editors, Tectonic Evolution of Southeast Asia (1996), pp. 445-463.

Wakita et al., 1996 K. Wakita, J.K. Sopaheluwakan, K. Miyazaki, I. Zulkarnain and Munasri, Tectonic evolution of the Bantimala complex, Geological Society of London, Special Publication, vol. 106 ,in: R. Hall, D.J. Blundell, Editors, Tectonic Evolution of Southeast Asia (1996), pp. 354-364.

Wensinck, 1997 H. Wensinck, Paleomagnetic data of Late Cretaceous rocks from Sumba, Indonesia; the rotation of Sumba continental fragment and its relations with eastern Sundaland. Geology in Minjbown, 76 1-2 (1997), pp. 57-71.

Wilson and Bosence, 1996 M.E.J. Wilson and D.W.J. Bosence, The Tertiary evolution of South Sulawesi: a record in redeposited carbonates of the Tonasa limestone formation, Geological Society of London, Special Publication, vol. 106 ,in: R. Hall, D.J. Blundell, Editors, Tectonic Evolution of Southeast Asia (1996), pp. 365-390.

Wilson et al., 1998 P. Wilson, J. Rais, C. Reigber, E. Reinhart, B.A.C. Ambrosius, X. Le Pichon, M. Kasser, P. Suharto, Dato Abdul Majid, Dato 'Paduka Hawang Haji Othman Bin Haji Yaakub, R. Almeda and C. Boonphakdee, GPS study provides data on active plate tectonics in Southeast Asia Region. EOS transactions American Geophysical Union, 79 (1998), pp. 545-549.

Yeates et al., 1987 A.N. Yeates, M.T. Bradshaw, J.M. Dickins, A.T. Brakel, R.P. Langford, S.M. Mullholland, J.M. Totterdell and M. Yeung, The Westralian superbasin: an Australian link with Tethys, K.G. McKenzie, Editor, Proceedings of the International Symposium on Shallow Tethys 2, A.A. Belkema, Rotterdam (1987), pp. 199-213. 

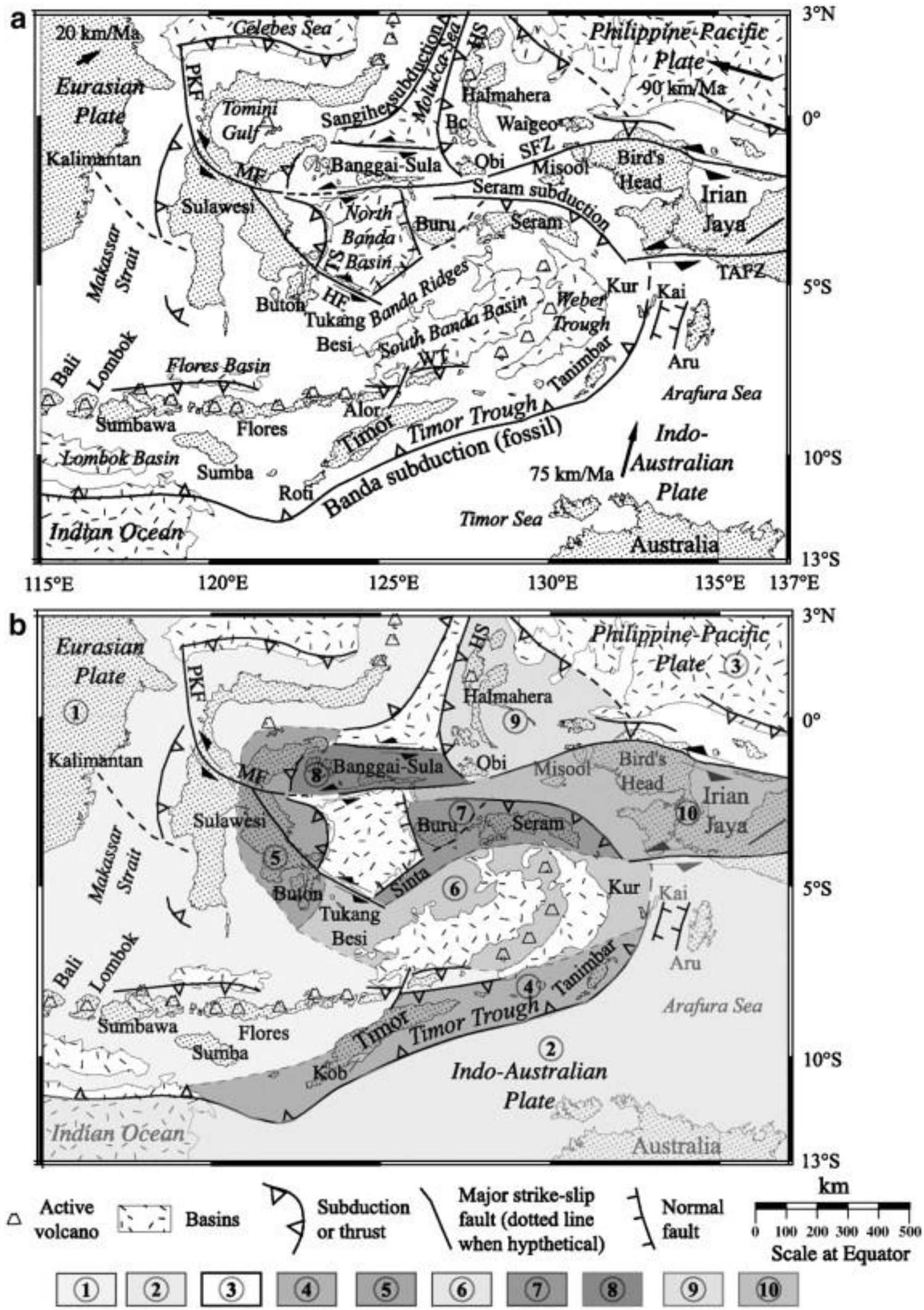

Fig. 1. : a. Physiography of the Eastern Indonesian area (modified after Honthaas et al., 1998). 1 - Emerged lands; 2 - metamorphic-volcanic type ridges; 3 - recent oceanic type crust basins or recently opened basins; 4 - Banda volcanic arc; 5 - submerged areas; 6 - active 
"subduction" zones; 7 - strike-slip fault. TAFZ: Aiduna-Tarera fault zone; HF: Hamilton fault zone; HS: Halmahera subduction zone; TS: Tolo subduction zone; PKF: Palu Koro fault zone; SFZ: Sorong fault zone, WT: Wetar thrust. b. The different tectonic plates, blocks, seas and basins in Eastern Indonesia. (1) Eurasian plate; (2) Indo-Australian plate; (3) PhilippinePacific plate; (4) Timor block; (5) Kolonodale block; (6) Lucipara block; (7) Seram block; (8) Banggai-Sula block; (9) Halmahera block; (10) Irian Jaya block. Kob: Kolbano terrane. 
Table 1.

\begin{tabular}{|c|c|c|c|c|c|c|c|c|c|c|}
\hline & $\begin{array}{l}\text { Lithostratigraphic } \\
\text { column }\end{array}$ & Location & $\begin{array}{l}\text { Geological unit } \\
\text { or formation }\end{array}$ & $\begin{array}{l}\text { Sample } \\
\text { ref. }\end{array}$ & $\begin{array}{l}\text { Age } \\
\text { (Ma) }\end{array}$ & \pm & $\begin{array}{l}\text { Error } \\
\text { at }(1 \\
\sigma)\end{array}$ & $\begin{array}{l}\text { Whole-rock } \\
\text { (WR) or } \\
\text { mineral }(\mathrm{M}) \\
\text { dated }\end{array}$ & Reference & Year \\
\hline 1 & Asiatic plate & $\begin{array}{l}\text { Central } \\
\text { Sulawesi }\end{array}$ & $\begin{array}{l}\text { Pompangeo } \\
\text { schists }\end{array}$ & n. p. & 114 & & n.p. & Mica (M) & Parkinson & 1991 \\
\hline \multirow[t]{2}{*}{$\begin{array}{l}1 \\
\mathrm{a}\end{array}$} & \multirow[t]{2}{*}{ Sulawesi } & $\begin{array}{l}\text { W } \\
\text { Sulawesi } \\
\text { Arm }\end{array}$ & Bantimala schists & n. p. & 111 & & n.p. & Muscovite (M) & Sukamto & 1982 \\
\hline & & Toraja area & Lamasi & $\begin{array}{l}\text { NL 30- } \\
\text { C }\end{array}$ & 158.5 & \pm & 5 & $\begin{array}{l}\text { Tholeitic basalt } \\
\text { (WR) }\end{array}$ & Priadi & 1993 \\
\hline \multirow[t]{5}{*}{$\begin{array}{l}1 \\
b\end{array}$} & \multirow[t]{5}{*}{ Sumba Island } & Jawila & Eastern edge & $\begin{array}{l}\text { CIA } \\
493\end{array}$ & 31.4 & \pm & 0.8 & Dacite (WR) & $\begin{array}{l}\text { Abdullah } \\
\text { et al. }\end{array}$ & \multirow[t]{5}{*}{2000} \\
\hline & & Lamboya & Rua beach & CIA 62 & 42.3 & \pm & 3.2 & Basalt (WR) & $"$ & \\
\hline & & Tanadoro & Western part & $\begin{array}{l}\text { CIA } \\
133\end{array}$ & 64.3 & \pm & 1.2 & $\begin{array}{l}\text { Granodiorite } \\
\text { (WR) }\end{array}$ & $"$ & \\
\hline & & $\begin{array}{l}\text { Wanokaka } \\
\text { beach }\end{array}$ & & $\begin{array}{l}\text { CIA } \\
317\end{array}$ & 70.3 & \pm & 1.5 & Basalt (WR) & $"$ & \\
\hline & & Masu & Cape Malangu & $\begin{array}{l}\text { CIA } \\
347\end{array}$ & 85.4 & \pm & 1.6 & $\begin{array}{l}\text { Granodiorite } \\
\text { (WR) }\end{array}$ & $"$ & \\
\hline $\begin{array}{l}1 \\
\mathrm{c}\end{array}$ & Timor Allochthonous & & Mutis complex & $\mathrm{T} 23$ & 153.6 & \pm & 3.4 & Basalt (WR) & Bellon & \\
\hline 4 & $\begin{array}{l}\text { Timor sub- } \\
\text { Allochthonous and } \\
\text { Autochthonous }\end{array}$ & & $\begin{array}{l}\text { Manamas } \\
\text { volcanic series }\end{array}$ & T 111 & 10.5 & \pm & 1.2 & $\begin{array}{l}\text { Diorite dike } \\
\text { (WR) }\end{array}$ & Bellon & \\
\hline \multirow[t]{2}{*}{5} & \multirow[t]{2}{*}{ Kolonodale block } & \multirow[t]{2}{*}{$\begin{array}{l}\text { East } \\
\text { Sulawesi }\end{array}$} & \multirow[t]{2}{*}{ Ophiolite } & SU 252 & 41.2 & \pm & 2.3 & $\begin{array}{l}\text { Magmatic } \\
\text { hornblende (M) }\end{array}$ & $\begin{array}{l}\text { Monnier et } \\
\text { al. }\end{array}$ & \multirow[t]{2}{*}{1994} \\
\hline & & & & SU 265 & 47.4 & \pm & 7.1 & $"$ & $"$ & \\
\hline \multirow[t]{4}{*}{6} & \multirow[t]{4}{*}{$\begin{array}{l}\text { Lucipara block and } \\
\text { Kur }\end{array}$} & \multirow[t]{4}{*}{ Kur } & \multirow[t]{4}{*}{$\begin{array}{l}\text { Metamorphosed } \\
\text { magmatic arc }\end{array}$} & $212 \mathrm{~K}$ & 23.9 & \pm & 1.7 & Diorite (WR) & $\begin{array}{l}\text { Honthaas } \\
\text { et al. }\end{array}$ & \multirow[t]{4}{*}{1997} \\
\hline & & & & Kur $7 \mathrm{j}$ & 16.9 & \pm & 1 & $\begin{array}{l}\text { Biotite (M) } \\
\text { paragneiss }\end{array}$ & $"$ & \\
\hline & & & & Kur 7i 1 & 29.9 & \pm & 1.7 & $\begin{array}{l}\text { Amphibole }(\mathrm{M}) \\
\text { norite }\end{array}$ & $"$ & \\
\hline & & & & Kur 7i 2 & 31.4 & \pm & 1.8 & $\begin{array}{l}\text { Amphibole (M) } \\
\text { hornblendite }\end{array}$ & $"$ & \\
\hline \multirow[t]{2}{*}{7} & \multirow[t]{2}{*}{ Seram block } & & & ABN $1 \mathrm{j}$ & 15.3 & \pm & 1.2 & $\begin{array}{l}\text { Transitional } \\
\text { basalt (WR) }\end{array}$ & \begin{tabular}{|l|} 
Monnier et \\
al.
\end{tabular} & 2003 \\
\hline & & & & ABN 6a & 8.9 & \pm & 0.4 & $\begin{array}{l}\text { Calc-alkaline } \\
\text { basalt (WR) }\end{array}$ & & \\
\hline \multirow[t]{3}{*}{8} & \multirow[t]{3}{*}{ Banggai-Sula block } & \multirow[t]{3}{*}{$\begin{array}{l}\text { Mangole } \\
\text { island }\end{array}$} & & WL 20P & 116 & \pm & 2.7 & Granite (WR) & $\begin{array}{l}\text { Bellon, } \\
\text { Rubini, }\end{array}$ & \multirow[t]{3}{*}{ unpubl } \\
\hline & & & & WK 8 & 220 & \pm & 5 & $\begin{array}{l}\text { Granodiorite } \\
\text { (WR) }\end{array}$ & $"$ & \\
\hline & & & & $\begin{array}{l}\text { WL 15- } \\
2\end{array}$ & 287 & \pm & 6.7 & Gabbro (WR) & $"$ & \\
\hline \multirow[t]{5}{*}{$\begin{array}{l}10 \\
b\end{array}$} & \multirow[t]{5}{*}{$\begin{array}{l}\text { Irian Jaya } \\
\text { Allochthonous }\end{array}$} & \multirow[t]{3}{*}{ Cyclops } & \multirow[t]{3}{*}{ Sentani } & Су 219 & 29.5 & \pm & 0.7 & $\begin{array}{l}\text { Back-arc basalt } \\
\text { (WR) }\end{array}$ & \begin{tabular}{|l|} 
Monnier et \\
al.
\end{tabular} & \multirow[t]{3}{*}{1999} \\
\hline & & & & Cy 218 & 29.3 & \pm & 0.7 & $"$ & $"$ & \\
\hline & & & & Сy 231 & 43 & \pm & 1 & Boninite & $"$ & \\
\hline & & \multirow{2}{*}{$\begin{array}{l}\text { Central } \\
\text { High } \\
\text { Range }\end{array}$} & \multirow[t]{2}{*}{ Sepik arc? } & HC 194 & 43 & \pm & 1 & $\begin{array}{l}\text { Calc-alkaline } \\
\text { basalt (WR) }\end{array}$ & Monnier & \multirow[t]{2}{*}{1996} \\
\hline & & & & HC 307 & 66 & \pm & 1.6 & Amphibole & $"$ & \\
\hline
\end{tabular}




\begin{tabular}{|c|c|c|c|c|c|c|c|c|c|}
\hline $\begin{array}{l}\text { Lithostratigraphic } \\
\text { column }\end{array}$ & Location & $\begin{array}{l}\text { Geological unit } \\
\text { or formation }\end{array}$ & $\begin{array}{l}\text { Sample } \\
\text { ref. }\end{array}$ & $\begin{array}{l}\text { Age } \\
\text { (Ma) }\end{array}$ & \pm & $\begin{array}{l}\text { Error } \\
\text { at }(1 \\
\sigma)\end{array}$ & $\begin{array}{l}\text { Whole-rock } \\
\text { (WR) or } \\
\text { mineral (M) } \\
\text { dated }\end{array}$ & Reference & Year \\
\hline & & & & & & & $\begin{array}{l}(\mathrm{M}), \\
\text { metagabbro }\end{array}$ & & \\
\hline & $\begin{array}{l}\text { Western } \\
\text { Mobile belt }\end{array}$ & Arc & 121 & 90 & \pm & 2.1 & $\begin{array}{l}\text { Microdiorite } \\
\text { (WR) }\end{array}$ & Prouteau & 1995 \\
\hline & \multirow[t]{2}{*}{$\begin{array}{l}\text { Central } \\
\text { High } \\
\text { Range }\end{array}$} & \multirow[t]{2}{*}{ Ophiolite } & HC 295 & 144 & \pm & 15 & $\begin{array}{l}\text { Amphibole } \\
(\mathrm{M}), \\
\text { metagabbro }\end{array}$ & Monnier & \multirow[t]{2}{*}{1996} \\
\hline & & & HC 304 & 157 & \pm & 16 & $\begin{array}{l}\text { Amphibole } \\
(\mathrm{M}), \\
\text { metagabbro }\end{array}$ & $"$ & \\
\hline
\end{tabular}

\section{EURASIAN PLATE-SUNDALAND INDO-AUSTRALIAN PLATE PHILIPPINE-PACIFIC PLATE}

(1)

\begin{tabular}{|c|}
\hline Pleistocene \\
\hline Pliocene \\
\hline Upper Mioc. \\
Middle Mioc. \\
Lower Mioc. \\
\hline \hline Oligocene \\
\hline Eocene \\
\hline Paleocene \\
\hline Cretaceous \\
\hline Jurassic \\
\hline Triassic \\
\hline \hline Permian \\
\hline Carboniferous \\
\hline
\end{tabular}

(2)

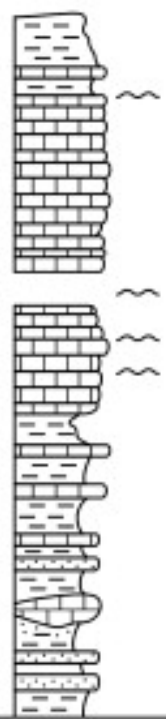

(3)

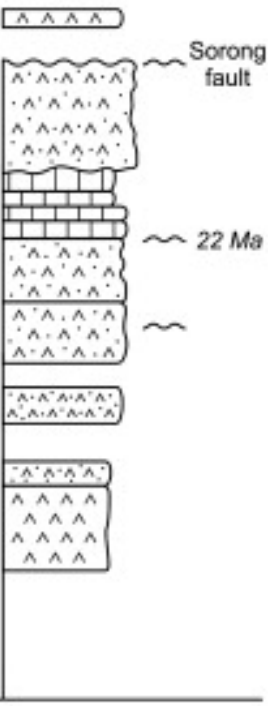

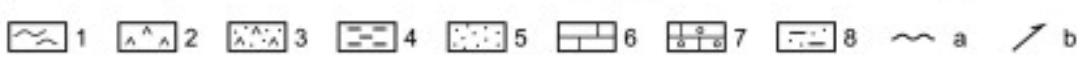

Fig. 2. : Lithostratigraphic sequences from the Eurasian plate (1), the Indo-Australian plate (2) and the Philippine plate (3). 1 - Metamorphic basement; 2 - basalts; 3 - volcanosedimentary rocks; 4 - shales; 5 - sandstones; 6 - limestones; 7 - oolithic limestones; 8 — siltstones; a - unconformity; b - thrust. 
WEST SULAWESI

(1a)

\begin{tabular}{|c|}
\hline Pleistocene \\
\hline Pliocene \\
\hline Upper Mioc. \\
Middle Mioc. \\
Lower Mioc. \\
\hline \hline Oligocene \\
\hline Eocene \\
\hline Paleocene \\
\hline Cretaceous \\
\hline Jurassic \\
\hline Triassic \\
\hline \hline Permian \\
\hline Carboniferous \\
\hline
\end{tabular}

SUMBA ISLAND

(1D)

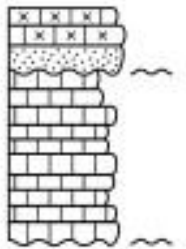

$31.4 \pm 0.8 \mathrm{Me}$ $42.3 \pm 3.2 \mathrm{Ma}$

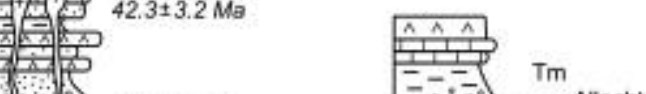

(10)

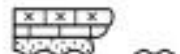

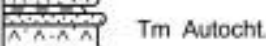

A.A.A. Miomaflo

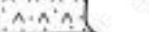

धणांव Cablac

Cablac

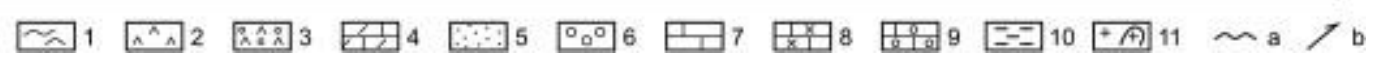

Fig. 3. : Lithostratigraphic successions on the Eurasian plate: North Sulawesi Arm (1a), Sumba Island (1b) and "Timor Allochthon" (1c). 1 - Metamorphic basement; 2 - basalts; 3 — ophiolites; 4 - radiolarites; 5 - sandstones; 6 - conglomerates; 7 - limestones; 8 reefal platforms; 9 - oolithic limestones; 10 - shales; 11 - granitic basement or intrusives; $\mathrm{a}$ - unconformity, $\mathrm{b}$ - thrust. 
TIMOR SUB-ALLOCHTONOUS and PARA-AUTOCHTONOUS

(4)

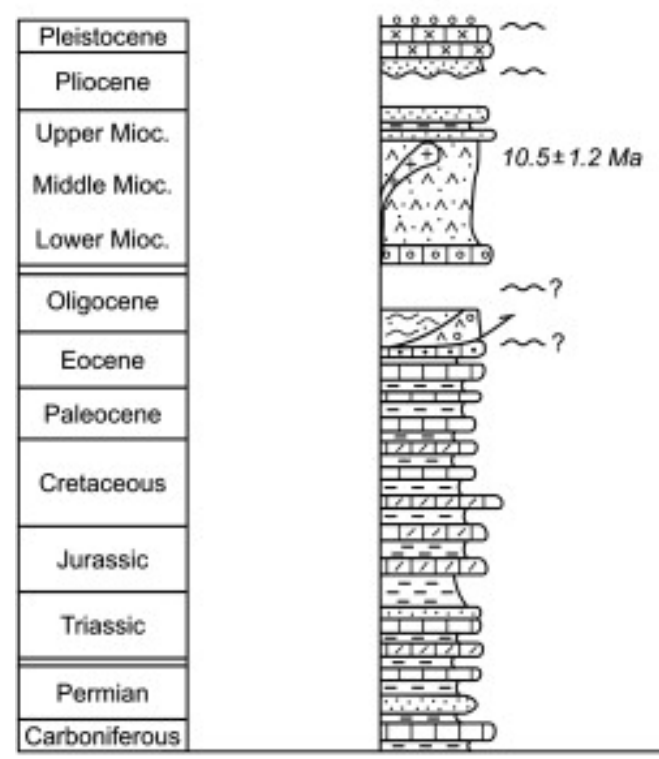

KOLONODALE BLOCK

(5)

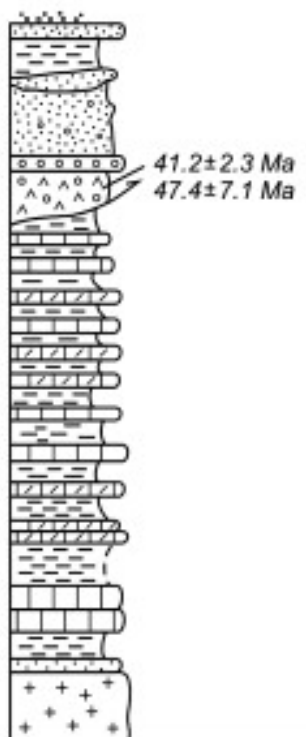

TANIMBAR ISLAND

(2b)

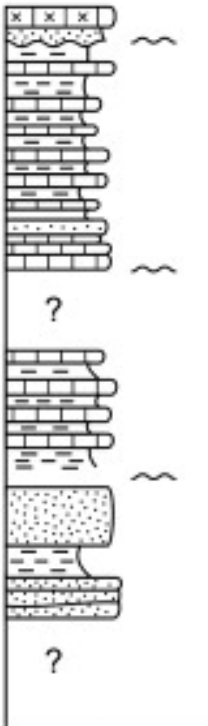

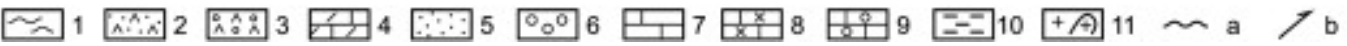

Fig. 4. : Lithostratigraphic successions on the Timor Para-Autochthonous (4), Kolonodale blocks (5) and on Tanimbar Island (2b). 1 - Metamorphic basement; 2 - volcanosedimentary rocks; 3 - ophiolites; 4 - radiolarites; 5 - sandstones; 6 - conglomerates; 7 — limestones; 8 - reefal platforms; 9 - oolithic limestones; 10 - shales; 11 - granitic basement or intrusives; $a-$ unconformity; $b$ - thrust. 
LUCIPARA KUR BLOCK

\begin{tabular}{|c|}
\hline Pleistocene \\
\hline Pliocene \\
\hline Upper Mioc. \\
Middle Mioc. \\
Lower Mioc. \\
\hline \hline Oligocene \\
\hline Eocene \\
\hline Paleocene \\
\hline Cretaceous \\
\hline Jurassic \\
\hline Triassic \\
\hline \hline Permian \\
\hline Carboniferous \\
\hline
\end{tabular}

(6)

HALMAHERA BLOCK

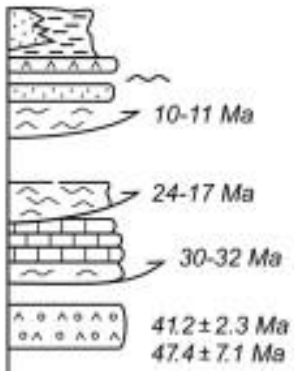

(9a)

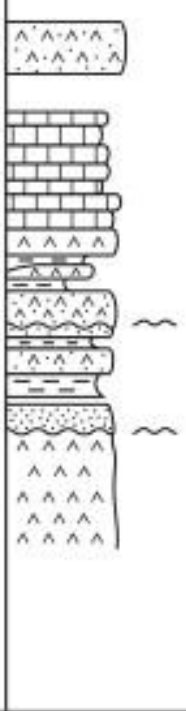

OBI ISLAND

(9b)

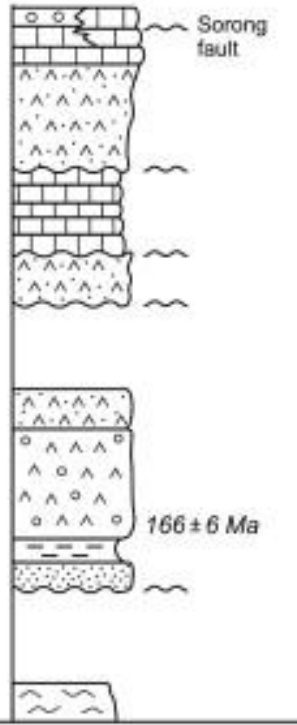

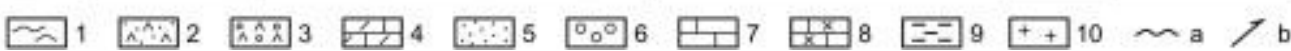

Fig. 5. : Lithostratigraphic successions on the Lucipara (6) and Halmahera blocks (9a) and Obi Island (9b). 1 - Metamorphic basement; 2 - Volcano-sedimentary rocks; 3 Ophiolites; 4 - Radiolarites; 5 - Sandstones; 6 - Conglomerates; 7 - Limestones; 8 Reefal platforms; 9 - Shales; 10 - Granitic basement; a - Unconformity; $b$ - Thrust. 


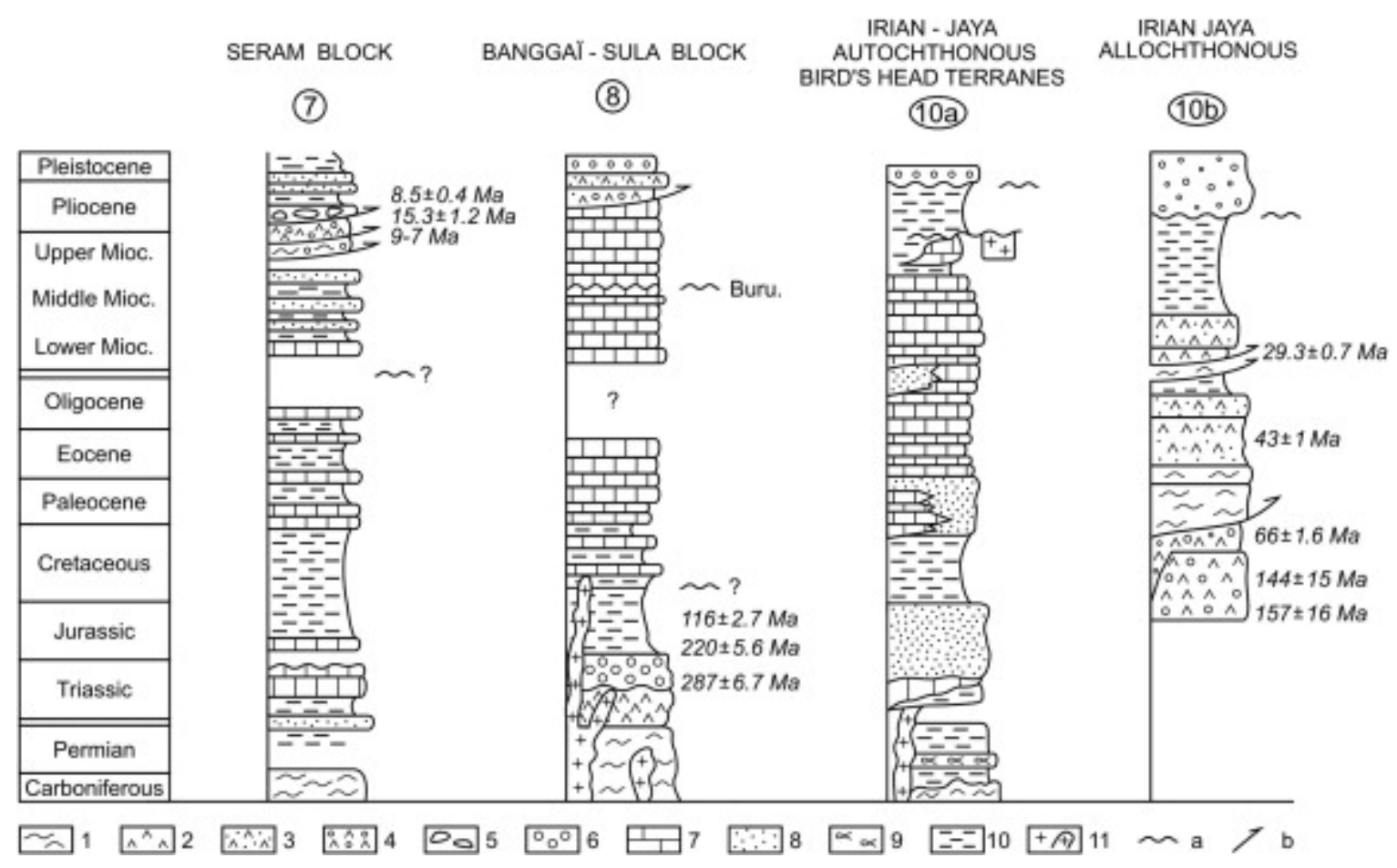

Fig. 6. : Lithostratigraphic successions on the Seram (7) and Banggai-Sula (8) blocks and on the "Irian Jaya Autochthonous", "Bird's Head terranes" (10a) and "Irian Jaya Allochthonous" (10b). 1 - Metamorphic basement; 2 - Basalts; 3 - Volcano-sedimentary rocks; 4 Ophiolites; 5 - Tectonic melanges; 6 - Conglomerates; 7 - Limestones; 8 - Sandstones; 9 - Amphibolites; 10 - Shales; 11 - Granitic or dioritic intrusions; a - Unconformity; b - Thrust. 


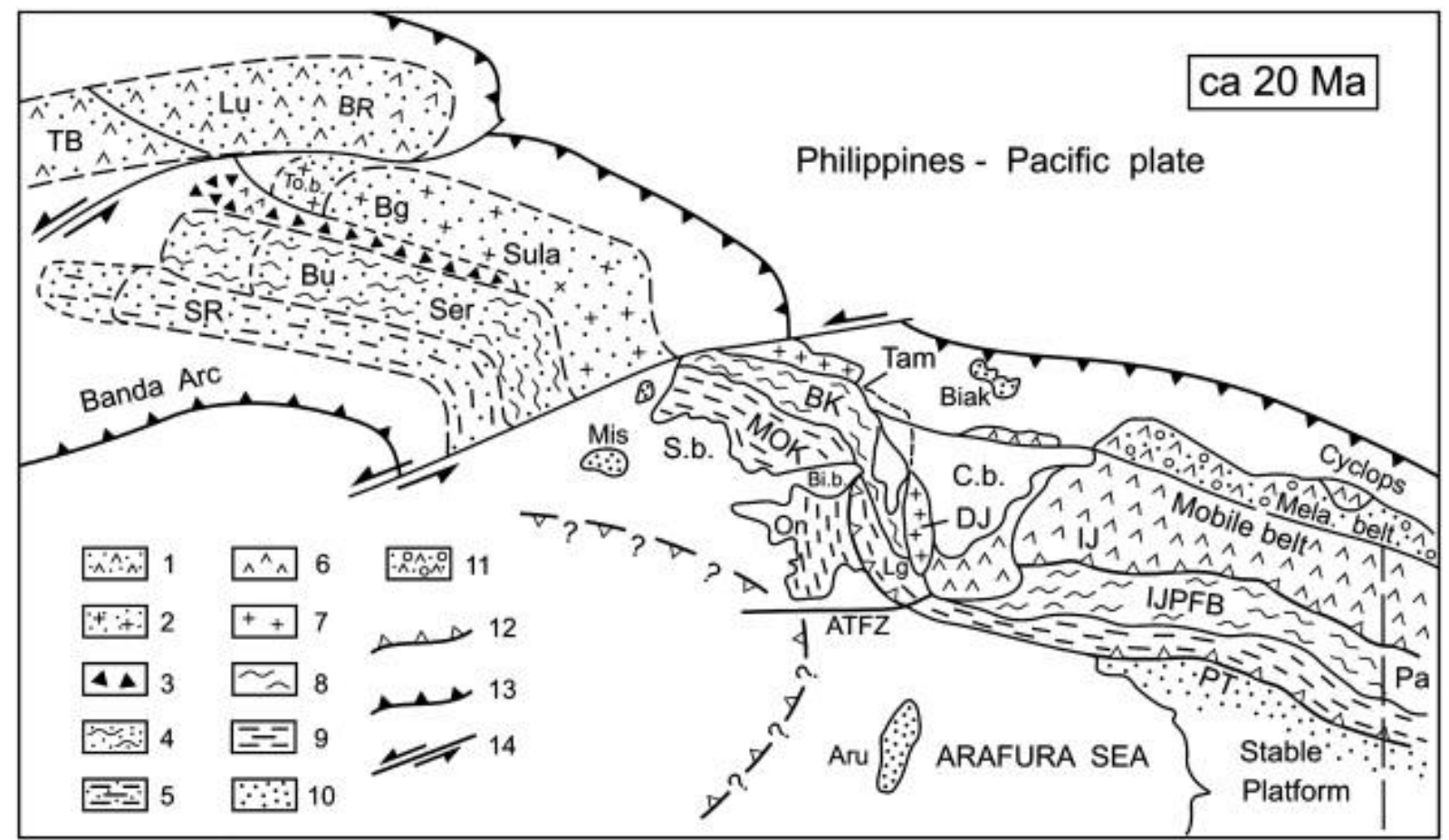

Fig. 7. : The Irian Jaya block (10) geological sketch map and its possible western extension to the Lucipara (6), Seram (7) and Banggai-Sula (8) blocks. 1 - Presumed Lucipara block; 2 Presumed Banggai-Sula block; 3 - Seram back-arc basin; 4 - Presumed Seram block; 5 Presumed Sinta Ridge terrane; 6 - Irian Jaya central ophiolite; 7 - Tamrau and Danau Jamar terranes; 8 - Bird's Head Kemum terrane, 9 - Onin-Lingurru terrane; 10 - Misool Island and the Irian Jaya stable platform; 11 - Melanesian Mobile belt; 12 - Subduction zone; 13 - Thrust; 14 - Strike-slip fault. For the abbreviations see Fig. 2 and Fig. 3. IJ = Irian Jaya island; $\mathrm{TB}=$ Tukang Besi, $\mathrm{Lu}=$ Lucipara, $\mathrm{BR}=$ Banda ridges, To. $\mathrm{b}=$ Tobelo basin, $\mathrm{Bg}=$ Banggai, $\mathrm{Bu}=$ Buru, Ser $=$ Seram, $\mathrm{SR}=$ Sinta ridges, Mis $=$ Misool, $\mathrm{Sb}=$ Salawati basin, Tam = Tamrau terrane, DJ = Danau Jambar terrane, On = Onin terrane, $\mathrm{Lg}=$ Lengguru terrane, $\mathrm{BK}=$ Bird's Head Kemum terrane, Mela.belt $=$ Melanesian belt, IJPFP = Irian Jaya Papuan Fold belt, $\mathrm{C} \cdot \mathrm{b}=$ Cenderawasih basin, $\mathrm{ATFZ}=$ Aiduna-Tarera fault zone, $\mathrm{PT}=$ Papuan thrust. 


\section{a}

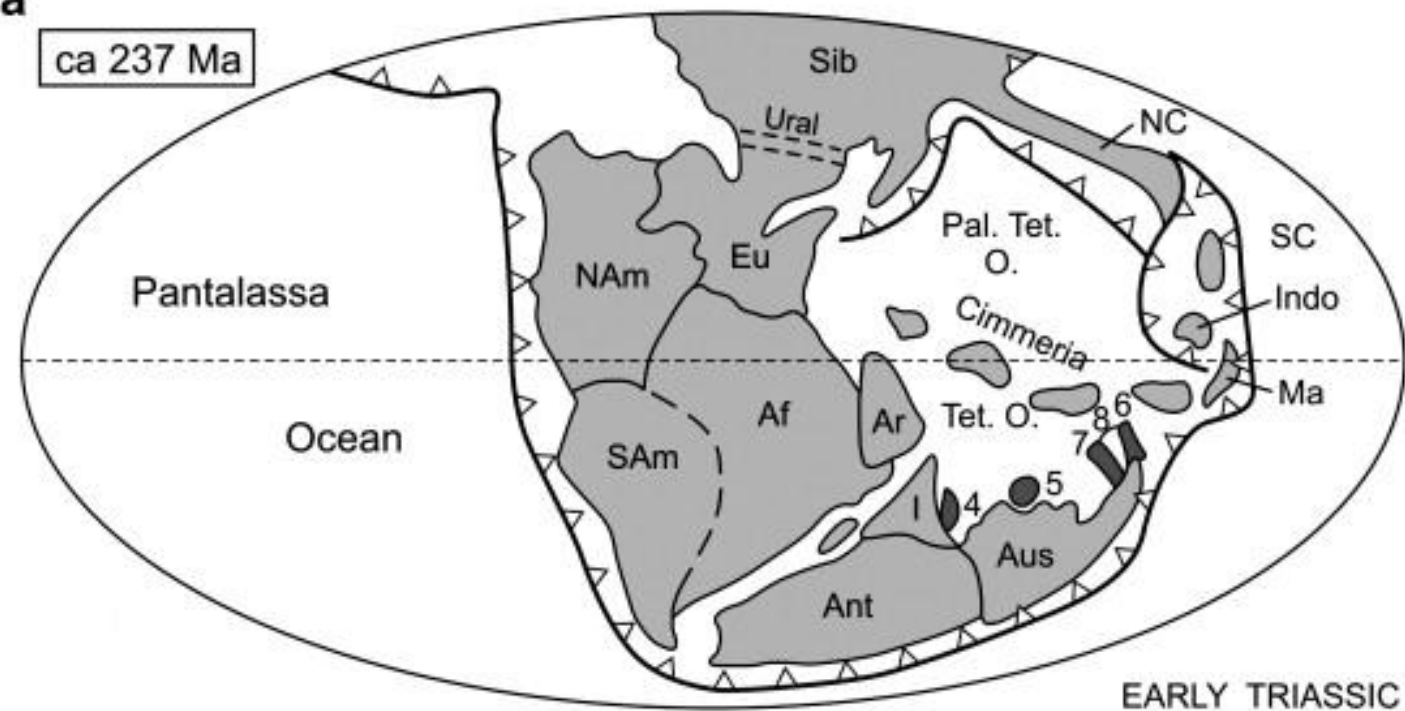

b

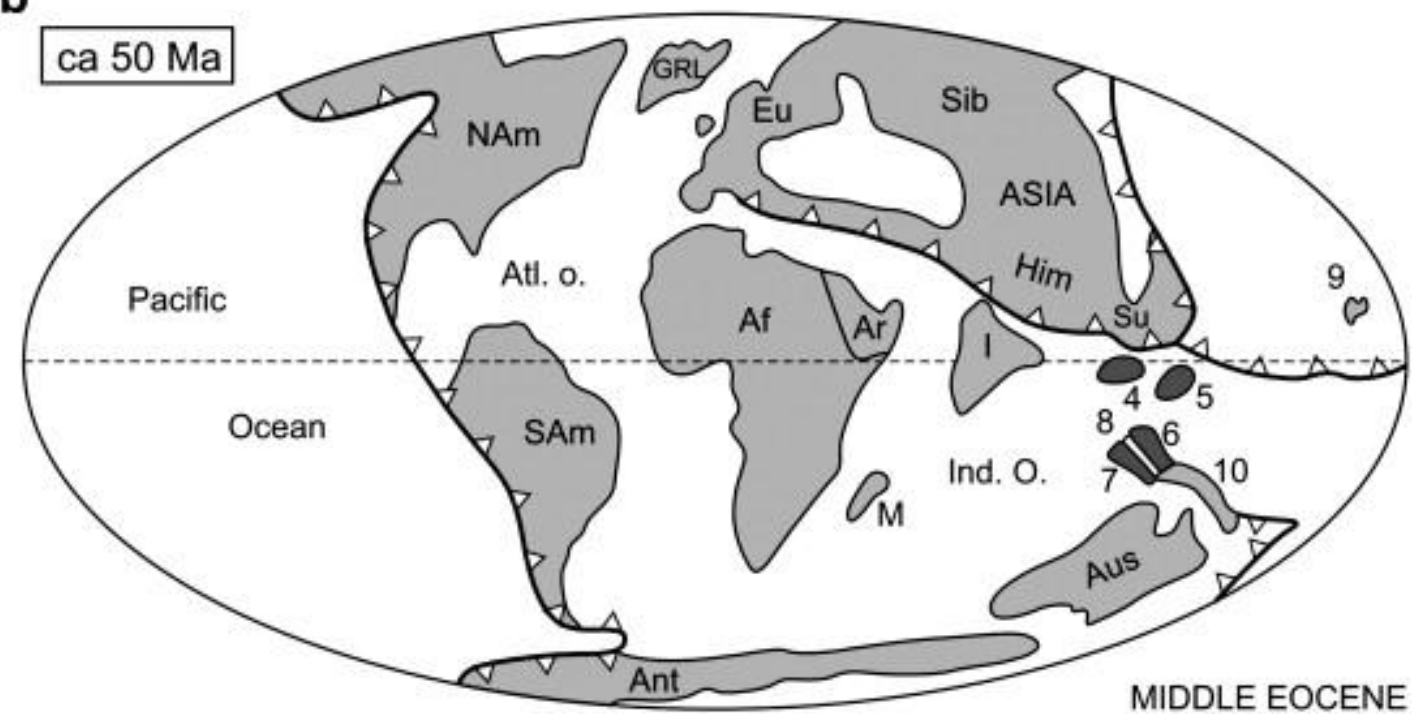

Fig. 8. : Palaeogeographic maps (modified after Scotese and Denham, 1987). 8a - Early Triassic: (4) Timor, (5) Kolonodale and 6 - Lucipara block; 7 - Seram block; 8 Banggai-Sula blocks location before their detachment from the Gondwana margin. $8 \mathrm{~b}-$ Middle Eocene: (4) Timor and (5) Kolonodale blocks are approaching the Eurasian margin close to Java and Sulawesi. 6 - Lucipara; 7 - Seram; 8 - Banggai-Sula; 9 - Halmahera and 10 - Irian Jaya blocks are still attached to the Australian continent. Common abbreviations for Fig. 10a and b: Atl.o.: Atlantic Ocean; Pal.Tet.o.: Paleo-Tethys Ocean; Tet.o.: Tethys Ocean; Ind.o.: Indian Ocean; Af: Africa; Ant: Antarctica; Ar: Arabia; Aus: Australia; EU: Europa; GRL: Groenland; Him: Himalaya; I: India; Indo: Indochina; M: Madagascar; Ma: Malaysia; NAm: North America; NC: North China; SAm: South America; SC: South China, Sib: Siberia; Su: Sumba. 


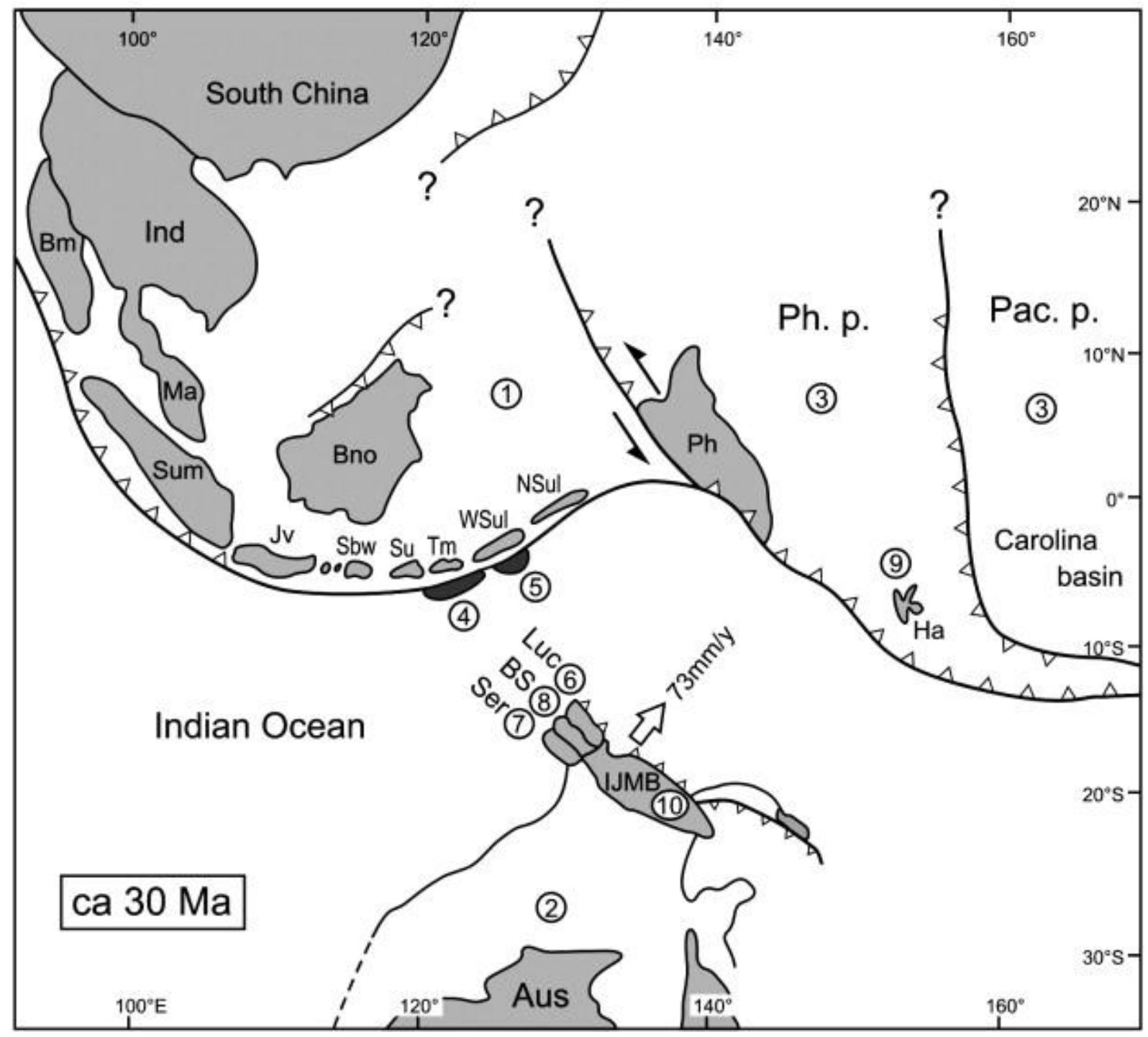

Fig. 9. : Palaeogeographic map for the Oligocene (30 Ma), modified after Lee and Lawver (1995). Timor (4) and Kolonodale (5) blocks are incorporated to the Eurasian margin and the Papua-New Guinea Island is approaching the Philippine plate. 1 - Eurasian plate; 2 - IndoAustralian plate; 3 - Ph.p.: Philippine plate and Pac.p.: Pacific plate; 4 - Timor block; 5 Kolonodale block; 6 - Lucipara block; 7 - Seram block; 8 - Banggai-Sula block: 9 Halmahera block; 10 - Irian Jaya block. Bm: Burma; Bno: Borneo; Ha: Halmahera; Ind: Indochina; IJMB: Irian Jaya Mobile belt; Jv: Java; Ma: Malaysia; N.Sul: North Sulawesi; Ph: Philippine block; Sbw: Sumbawa; Su: Sumba; Sum: Sumatra; Tm: Timor; WSul: West Sulawesi. 


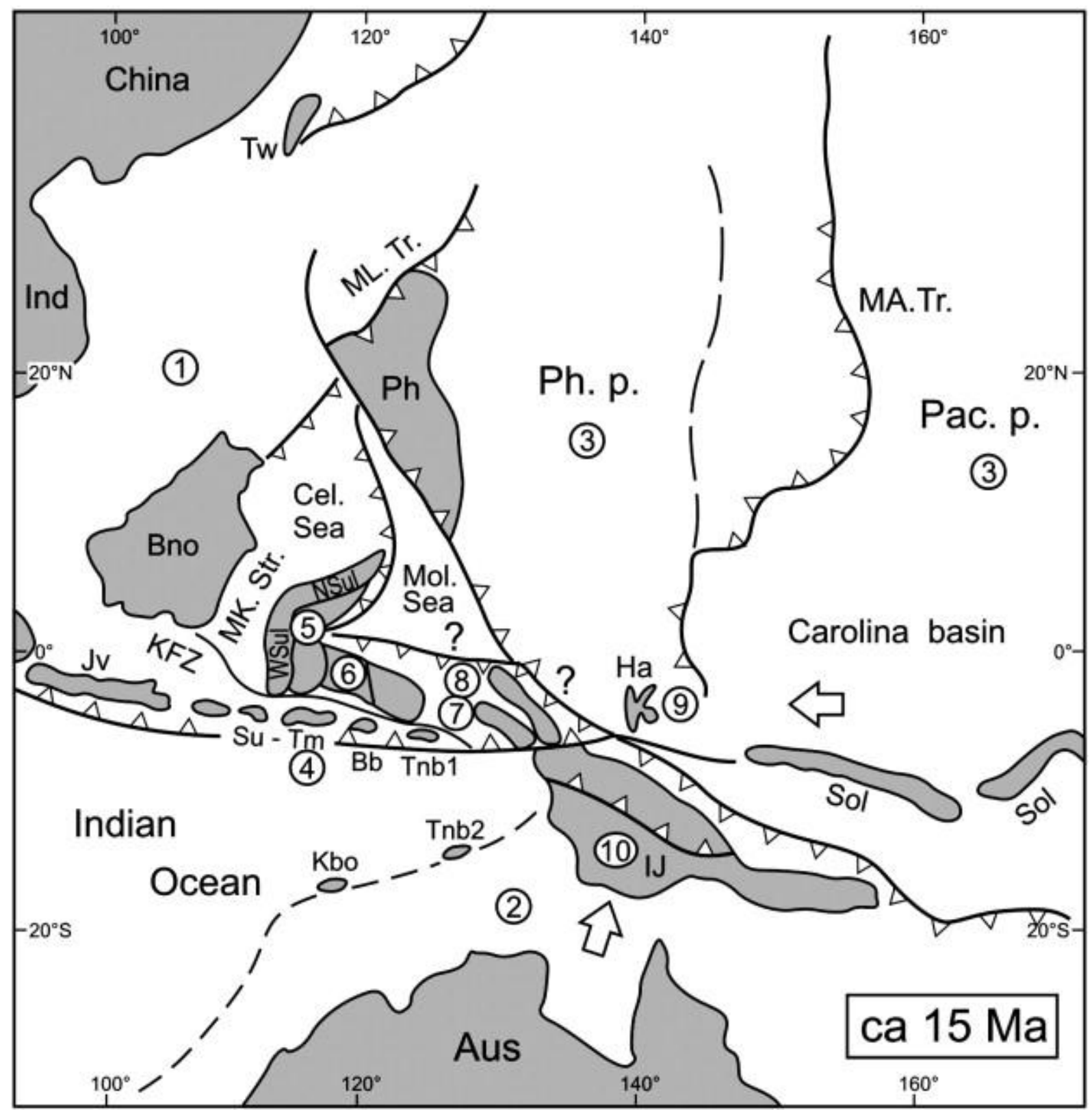

Fig. 10. : Palaeogeographic map by the Middle Miocene time (15 Ma), modified after Lee and Lawver (1995). Lucipara block (6) is close to Buton Island in the south-eastern part of Sulawesi and Seram (7) and Banggai-Sula blocks (8) moved to the West, away from Irian Jaya. Kolbano (Kbo) and Tanimbar 2 (Tnb2) terranes belong to the Australian margin. 1 Eurasian plate; 2 - Indo-Australian plate; 3 - Ph.p.: Philippine plate and Pac.p.: Pacific plate; 4 - Timor block; 5 - Kolonodale block; 6 - Lucipara block; 7 - Seram block; 8 Banggai-Sula block: 9 - Halmahera block; 10 - Irian Jaya block. Bb: Babar; Bno: Borneo; Cel.Sea: Celebes Sea; Ha: Halmahera; Ind: Indochina; Kbo: Kolbano terrane; KFZ: Kalao fault zone; IJ: Irian Jaya Mobile belt; Jv: Java; Ma: Malaysia; MA.Tr.: Mariana Trench; MK.Str.: Makassar strait; ML.Tr: Manila Trench; Mol.Sea: Moluccas Sea; N.Sul: North Sulawesi; Ph: Philippine block; Sol: Solomon Islands; Su: Sumba; Tm: Timor; Tnb1: Ungar Island; Tnb2: Tanimbar Island; Tw: Taiwan; WSul: West Sulawesi. 
